\title{
Digital Media: A Revolution in Reading Practices?
}

Investigating Avid Readers

Le numérique: une révolution dans les pratiques de lecture? Une enquête sur les grand.e's lecteur.rice's

Lo digital: ¿una revolución de las prácticas de lectura? Una investigación sobre los grandes lectores

\section{Gérard Mauger}

Translator. Alba Simaku

\section{Q OpenEdition}

\section{Electronic version}

URL: http://journals.openedition.org/bssg/481

DOI: $10.4000 /$ bssg.481

ISSN: 2490-9424

\section{Publisher}

Presses universitaires de Vincennes

\section{Electronic reference}

Gérard Mauger, "Digital Media: A Revolution in Reading Practices?", Biens Symboliques / Symbolic Goods [Online], 7| 2020, Online since 20 November 2020, connection on 04 March 2021. URL: http:// journals.openedition.org/bssg/481 ; DOI: https://doi.org/10.4000/bssg.481 
BIENS

SYMBOLIQUES

SYMBOLIC

GOODS
SYMBOLIQUES

Revue de sciences sociales sur les arts, la culture er les ides
A Social Science Journal on Arts. Culture and Ideas SYMBOLIC $\infty 2$ GOODS

is leurs racine tra

It des cassolettes d'encens et'finim

fums à la fois. Tout rit, chonte et

loucement ivre. Le printemps est

e; le soleil aide à faire patienter

des êtres qui n'en demandenit pas

gui, ayant l'azur du ciel, disenf

absorbés dans le prodige, jpuisant

la nature l'indifference du bien 2

ateurs du cosmos radieusement dist mi ne comne $n^{\circ} 7 / 2020$ as amion shasm

\section{Lire en numérique} Digital Readings 
Le numérique : une révolution dans les pratiques de lecture?

Une enquête sur les grand.e.s lecteur-rice's
Digital Media: A Revolution in Reading Practices?

Investigating Avid Readers

Gérard Mauger

traduction | translation

Alba Simaku

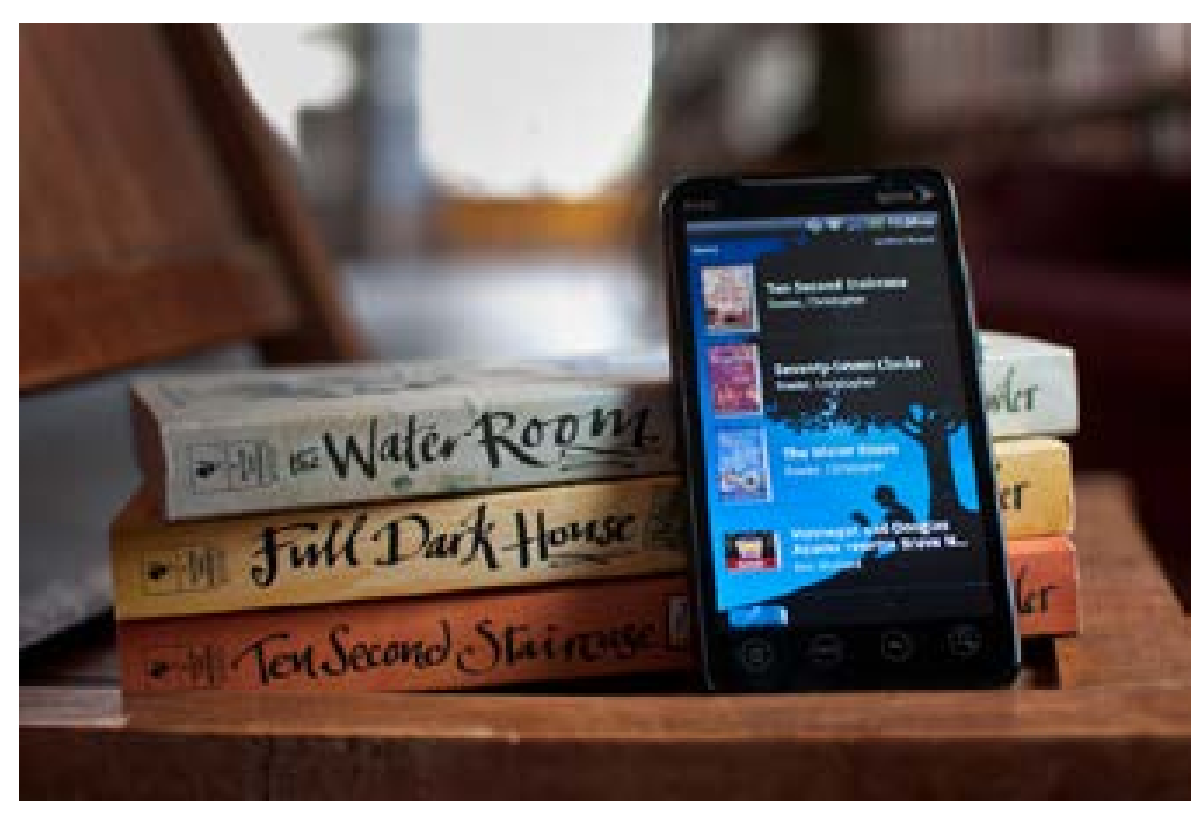

Fig. 1. Du livre à la liseuse / From books to e-books

Source: Flickr, photo de Pen Waggener / Flickr, picture by Pen Waggener 
En montrant ce que le sens d'un texte doit à sa forme matérielle, Donald F. McKenzie (1991) invitait à ne jamais séparer " la compréhension historique des écrits de la description morphologique des objets qui les portent ». Reprenant cette perspective à son compte, Roger Chartier (2008 : 18) propose de " toujours associer dans une même analyse les rôles attribués à l'écrit, les formes et les supports de l'écriture et les manières de lire ». Ce précepte invite évidemment à interroger aujourd'hui les incidences de la "révolution numérique » sur les pratiques de lecture : selon Chartier (2008 : 20), « en brisant le lien noué entre les textes et les objets, entre les discours et leur matérialité, [elle] oblige à une radicale révision des gestes et des notions que nous associons à l'écrit ". Tel fut l'objet d'une enquête sur des pratiquant $\cdot e \cdot s$ intensif $\cdot v e \cdot s$ de la lecture numérique en réponse à un appel d'offre de la Bibliothèque publique d'information (BPI) du Centre Pompidou (Gaudric, Mauger, Zunigo 2015), dont on se propose d'exposer ici les principales conclusions ${ }^{1}$.

Parce que la « révolution numérique » se prête, comme tout phénomène apparenté, au déploiement symétrique de la célébration et de la déploration (voir Fig. 2. Mythologies de la « révolution numérique $»)^{2}$, on peut tenter d'abord de se prémunir des travers

1. Plus précisément, cet article reprend les grandes lignes de la conclusion de l'ouvrage cité que j'avais rédigée à la demande de Xaver Zunigo (le responsable du projet) en n'en retenant que celles qui concernaient les pratiques de lecture et en les complétant par des données empiriques issues de l'enquête menée.

2. Que ce soit pour le célébrer ou le déplorer, les prophéties s'accordent sur l'importance du bouleversement : « une mutation est en cours, irréversible, et qui emporte avec elle ce à quoi nous devons le meilleur de ce que nous sommes », " ce qui s'amorce est tout aussi irréversible et total que les précédentes mutations de l'écrit, et des usages et formes de lecture que chacune a initiés ", écrit, par exemple, François Bon (2011: 7) qui constate, par ailleurs, «l'opacité de la mutation numérique du livre » (2011: 112).
Donald F. McKenzie (1991) urged against separating "the historical understanding of written works from the morphological description of the objects that carry them," thereby illustrating how the meaning of a text is dependent upon its material form. Roger Chartier (2008: 18) followed suit, suggesting that "the roles attributed to writing, writing forms, and mediums, and the various methods of reading should always be associated in one analysis." This precept naturally leads us to question the impact of the "digital revolution" on reading practices. According to Chartier (2008: 20), "[the revolution] obliges a radical review of the gestures and notions that we associate with the written word, since it breaks the link between text and object, discourse and its materiality." What follows are the main conclusions from a survey on avid digital readers who responded to a request from the Georges Pompidou's Bibliothèque publique d'information (BPI) (Gaudric, Mauger, Zunigo 2015)'.

Like all similar phenomena, the "digital revolution" is as equally celebrated as it is deplored (see "digital revolution myths" chart) ${ }^{2}$. It is therefore necessary to guard against the pitfalls that threaten an investigation of this type. To escape this fate and the "myths"

1. This article takes up the main concluding remarks in the cited text, written on Xaver Zunigo's request. I retained parts that concerned reading habits and with added empirical data from the survey.

2. Whether this upheaval is deemed celebratory or is deplored, predictions all seem to agree on its importance. For instance, Francois Bon, who ascertains the "opacity of the books" digital mutation' (2011: 112), writes: "a transformation is occurring. It is irreversible and it is taking with it the very best part of ourselves," "it is just as all-encompassing and irreversible as the writing evolutions that preceded, in the uses and forms of reading that each initiated" (2011: 7). 
auxquels expose toute enquête sur ce genre de « révolution ». Pour échapper à cette alternative et aux « mythologies » qui vont de pair $^{3}$, il faut essayer de repérer, vingt-cinq ans après la naissance du Web, ce qui change dans "la révolution »: les discontinuités, bien sûr, mais aussi les continuités. Côté continuité, Robert Darnton (2011 : 16) rappelle le pouvoir étonnamment pérenne du livre ${ }^{4}$. De même, Chartier (2008 : 19) remarque à propos de l'invention de l'imprimerie qu'elle n'a pas modifié les structures fondamentales du livre (celles du codex) et qu'il y a une très forte continuité entre la culture du manuscrit et la culture de l'imprimé ${ }^{5}$. S'il est vrai que l'ampleur des bouleversements provoqués par la « révolution numérique » incite à la comparer à celle de Gutenberg, sans doute faut-il plutôt identifier les continuités et circonscrire les ruptures qu'annoncer une rupture totale entre culture de l'imprimé et culture numérique (que ce soit pour la célébrer ou pour la déplorer). Quant aux bouleversements induits par la « révolution numérique » en matière d'écriture, on peut distinguer ceux - considérables - qui affectent à la fois la production, la reproduction, la distribution et la conservation des textes (l'écriture) et ceux qui modifient leur appropriation (la lecture) ${ }^{6}$.

3. II semble, en effet, que les « révolutions technologiques » en matière de médias soient un terrain particulièrement propice aux discours prophétiques qui, balançant « entre l'indémontrable et le même-pas-faux », esquivent les questions terre-à-terre susceptibles de les mettre en question. L'enquête, dont se dispensent les prophètes, conduit à une évaluation plus modeste du phénomène, de ses nuances et de ses limites (Bourdieu \& Passeron, 1963).

4. « À certains égards, le codex est supérieur à l'ordinateur, note-t-il. Vous pouvez le feuilleter, l'annoter, l'emporter au lit avec vous et le range commodément sur un rayonnage » (2011: 177). Dans la même perspective, cf. la vidéo espagnole « Nouvelle technologie révolutionnaire ! Book».

5. Voir Chartier (1997: 9) et Eisenstein (1979).

6. Selon Roger Chartier (2008: 56), la notion d'appropriation « renvoie tant aux catégories intellectuelles et esthétiques des différents publics qu'aux gestes, aux habitudes, aux conventions qui règlent leurs relations à l'écrit » that accompany it ${ }^{3}$, twenty-five years after the birth of the internet, we must try to identify changes in "a revolution," both in terms of discontinuities and continuities. Regarding the latter, Robert Darnton (2011: 16) reminds us of the surprising lasting power of books ${ }^{4}$. Similarly, Chartier (2008: 19) noted that the invention of the printing press has not modified the fundamental structures of books (the codex) and that there is a strong continuity between the manuscript and printing press cultures ${ }^{5}$. We could go as far as saying that the "digital revolution" can be compared to Gutenberg's revolution, in which case, the continuities must be identified and ruptures circumscribed, instead of announcing a total break between the printing press and digital culture (whether celebrated or deplored). As for the considerable changes to written texts induced by the digital revolution, we differentiate between those that affect production, reproduction, distribution and conservation of texts (writing), from those that concern their appropriation (reading) ${ }^{6}$

3. Indeed, it seems that the "technological revolutions" in media terms are a particularly conducive ground for prophetic discourse, which oscillate "between the indemonstrable and the not-even-wrong," shirking from any subversive down-to-earth questions. The survey leads to a more modest evaluation of the phenomenon and its nuances and limits, that the predictions tend to ignore (Bourdieu \& Passeron 1963).

4. "In some respects, the codex is superior to the computer", he writes. "You can leaf through it, annotate it, take it to bed with you and easily put it away on a bookshelf" (2011: 177). In the same perspective, see the Spanish video "New Technological Revolution! Book".

5. See Chartier (1997: 9) and Eisenstein (1979)

6. According to Roger Chartier (2008: 56), the concept of appropriation "designates intellectual and aesthetic categories for different kinds of audience, as well as the gestures, habits and conventions that rule their relationship to the written word." 


\begin{tabular}{|c|c|}
\hline \multicolumn{2}{|c|}{$\begin{array}{l}\text { Une revelution culturelle } \\
\text { Une modification radlicale de nos maniteres de penser } \\
\text { et to nous comporter }\end{array}$} \\
\hline \multicolumn{2}{|c|}{ Metamorphoses de Fecriture } \\
\hline ofrutakex & chúantay \\
\hline 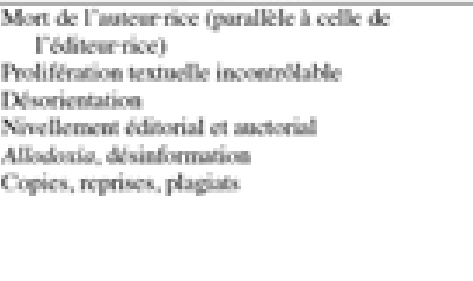 & 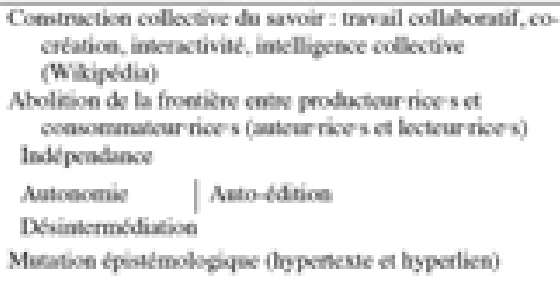 \\
\hline \multicolumn{2}{|c|}{ matamorphoses de a respace publle : } \\
\hline 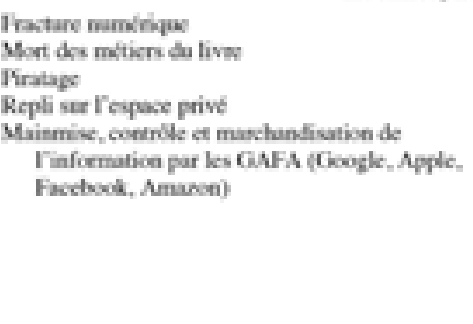 & 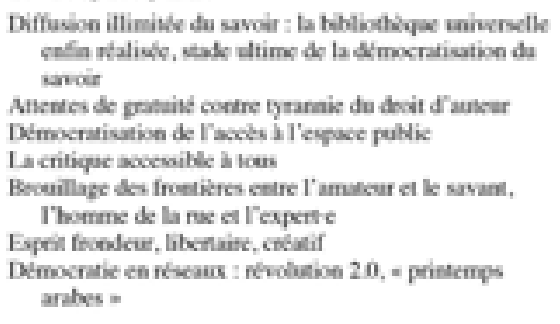 \\
\hline \multicolumn{2}{|c|}{ Hetamorntoses te la lecture } \\
\hline 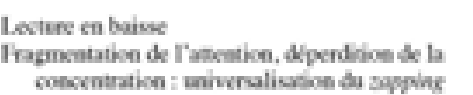 & 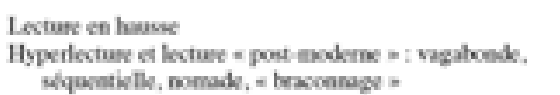 \\
\hline
\end{tabular}

Fig. 2. Mythologies de la « révolution numérique »

c) Gérard Mauger

\section{La lecture en hausse ?}

Dans la perspective de longue durée qu'adopte Pierre Bergounioux (2019 : 42, 44), « la pensée » (associée à l'écriture) semblait devoir rester éternellement prisonnière du papier : " matériel, comme tous ses antécédents, il avait un volume, un poids, un prix et il était

\begin{tabular}{|c|c|}
\hline \multicolumn{2}{|c|}{$\begin{array}{l}\text { A radical change in our thought and behavioer } \\
\text { An entirely inreversilile translornation }\end{array}$} \\
\hline \multicolumn{2}{|c|}{ The evolution of writing } \\
\hline Denthi & Cutetantia \\
\hline 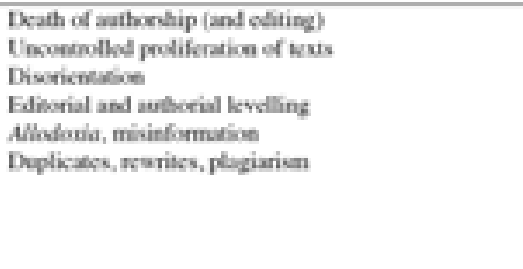 & 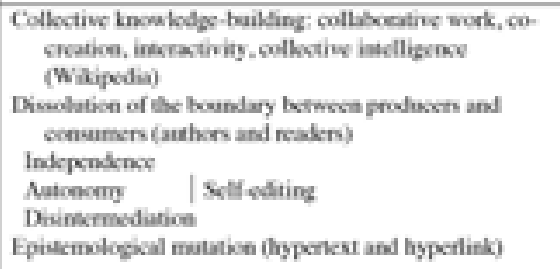 \\
\hline \multicolumn{2}{|c|}{ The evolution of "puthlic space" } \\
\hline 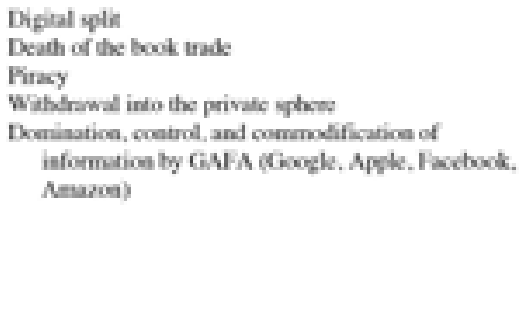 & 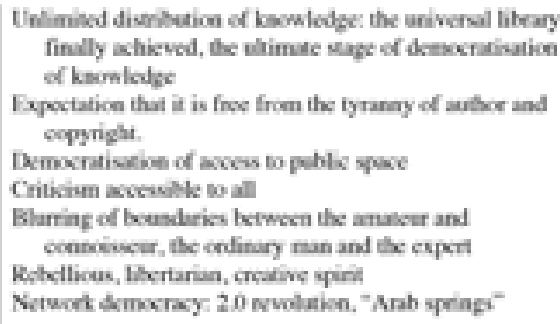 \\
\hline \multicolumn{2}{|c|}{ The evolution of readling } \\
\hline 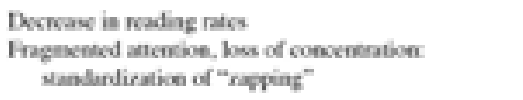 & 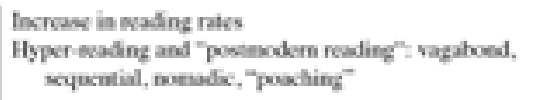 \\
\hline
\end{tabular}

Fig. 2. Mythology of the "digital revolution" (c) Gérard Mauger

\section{Is Reading on the Rise?}

In Pierre Bergounioux's (2019: 42, 44) long-term perspective, "thought" (associated with writing) seemed eternally bound to remain prisoner of paper: "material, like all of its antecedents, it had a volume, a weight, a price and it was localised," he writes. 
localisé », écrit-il. Or, avec la révolution numérique, « le sens s'est affranchi de l'ancrage matériel auquel il était inféodé depuis son apparition vers le milieu du quatrième millénaire en Mésopotamie » (ibid. : 16). "Les signes, avec le numérique, se sont délestés de leur assise matérielle, désincarnés. Ils circulent, sous forme binaire, à la vitesse de la lumière » (ibid. : 44, 46), de sorte que l'information est devenue immédiatement et partout disponible : « ni les routes, ni les jours ne s'interposent plus entre les plus reculés cantons et l'immense trésor des signes accumulés, archivés, ordonnés 》 (ibid. : 58). Mais on peut se demander si cette transformation radicale des conditions d'accès à « la culture » liée à la dématérialisation des contenus, à la généralisation de l'internet à haut débit (« ce média à tout faire ", comme dit Olivier Donnat [Donnat 2009]) et aux progrès considérables de l'équipement informatique des ménages (ordinateurs, tablettes, liseuses, etc.) a également bouleversé les pratiques culturelles et, plus spécifiquement, les pratiques de lecture.

Or, s'il est vrai que la lecture numérique a cessé d'être le monopole de quelques « technophiles ", il s'avère qu' " en matière de lecture d'imprimés, les deux principales tendances à l'œuvre depuis les années 1980 se sont poursuivies au cours de la dernière décennie : la lecture quotidienne de journaux (payants) a continué à diminuer, de même que la quantité de livres lus en dehors de toute contrainte scolaire ou professionnelle ». Depuis plusieurs décennies, chaque nouvelle génération arrive à l'âge adulte avec un niveau d'engagement dans la lecture de presse ou de livres inférieur à la précédente : en 2008, $53 \%$ des enquêté.e.s déclaraient spontanément lire peu ou pas du tout de livres (Donnat $2009)^{7}$. L'accessibilité des textes ne semble pas en avoir généralisé

7. Plus récemment, selon l'enquête IPSOS-CNL (Vincent Gérard et Poncet, 2019), 40 \% des Français·es se déclaraient " pas ou peu lecteur.rice-s " (mais avec des critères de classement différents de ceux des enquêtes PCF).
Yet with the digital revolution, "meaning has freed itself from the material anchoring upon which it was dependent since its appearance around the fourth millennium in Mesopotamia" (ibid.: 16). "Signs, in the digital age, have been off-loaded from their material base, disembodied. They now circulate in binary form, at the speed of light" (ibid:: 44, 46), in such a way that information is now available anywhere at all times: "neither roads nor days stand between the most far-out communes and the immense treasure of accumulated, archived and ordered signs" (ibid.: 58). However, we may question whether this radical transformation of conditions to access "culture"-linked to an increasingly dematerialized system, the spread of high-speed internet ("all-purpose media" as Olivier Donnat, 2009, calls it) and the considerable improvement of home IT equipment (computers, tablets, e-readers)-has also disturbed cultural practices and, more specifically, reading habits.

Yet, while it is true that digital reading has ceased to be in the sole control of a handful of "technophiles," it turns out that "when it comes to reading printed texts, the two main tendencies at work since the 1980 s have continued into the last decade: daily reading of (paid) newspapers continues to decline, as well as the number of books read outside of any scholarly or professional constraint." Over the last few decades, each new generation of adults possesses an inferior level of reading newspapers or books compared with the generation before. In $2008,53 \%$ of those surveyed impulsively revealed that they read very few or no books at all (Donnat 2009) ${ }^{7}$. The current availability of texts does not seem to be altogether

7. More recently, according to the IPSOS-CNL survey (Vincent \& Gerard Poncet 2019), 40\% of French citizens described themselves as "non-readers or rare readers" (but with classification criteria that differed to that of the PCF survey). 
l'accès ${ }^{8}$. Toutefois, dans la mesure où cette baisse tendancielle des pratiques de lecture est antérieure à la « révolution numérique », il semble difficile de la lui imputer.

En fait, il se peut que la déploration de la «baisse de la lecture " (Mauger 1992) ${ }^{9}$ qui a succédé depuis longtemps à la crainte de la prolifération des lectures incontrôlées et de la multiplication des lecteur.rice-s incontrôlables (Chartier \& Hébrard 2000) méconnaisse la pluralité des types de lecture et, en particulier, la lecture sur écran. Si le livre conserve une position élevée dans la hiérarchie des biens culturels et si la lecture demeure une pratique culturelle distinguée et hautement valorisée, on assiste peut-être, plus qu'à un déclin de la lecture, à une évolution des pratiques de lecture ${ }^{10}$. On peut même attribuer à la "révolution numérique » une extension des pratiques de lecture. Selon Chartier, " jamais aucune société n'a lu autant, jamais on a autant publié de livres (même si les tirages ont tendance à baisser), jamais il n'y a eu autant de matériel écrit disponible à travers les kiosques ou les marchands de journaux, et jamais on a autant lu du fait de la présence des écrans » (Chartier

8. Parallèlement, les différences entre classes sociales ont tendance à se creuser du fait du décrochage des d'une partie des classes populaires (notamment ouvrières), de même que les écarts entre hommes et femmes : $62 \%$ des hommes déclarent lire peu ou pas du tout de livres contre $46 \%$ de femmes (Donnat 2009).

9. Selon Layla Ricroch et Benoît Roumier (2011), le temps consacré par les Français es à la lecture de livres et de journaux (y compris sur Internet) a diminué d'un tiers depuis 1986 pour atteindre dix-huit minutes par jour en moyenne en 2010. De façon générale, on peut rendre compte de la baisse des pratiques de lecture littéraire par la place prise par les mathématiques dans la définition de l'excellence scolaire et par celle de l'audiovisue (cinéma, télévision, vidéos, jeux vidéo) dans la quête de « divertissement ». Sur la notion de « divertissement », voir Mauger \& Poliak (1998).

10. Selon Claire Bélisle (2011), par exemple, le reflux du roman se ferait au profit du développement de la lecture d'information et d'opinion. widespread ${ }^{8}$. However, it is difficult to attribute the downturn to accessibility, as far as this tendential decline in reading habits predates the digital revolution.

It is in fact possible that denouncing "declining reading rates" (Mauger $1992^{\circ}$ )-which has long since replaced the fear of widespread out-of-control reading and an increase in uncontrollable readers (Chartier \& Hébrard 2000)-leads to a disregard of the plurality of reading types, specifically regarding on-screen reading. If books continue to occupy an elevated position in the hierarchy of cultural goods, and if reading remains a culturally distinguished and highly valued practice, we may instead be witnessing an evolution in reading practices, rather than a decline in reading ${ }^{10}$. The digital revolution can even be said to be boosting reading practices. According to Chartier, "never has a society read so much, never have so many books been published (even though fewer are usually printed), never has there been this much written material available in kiosks and newsagents, and never have we read this much, due to the presence of screens" (Chartier 2013). The issue of quantitative variations in reading habits brings up the question

8. At the same time, the gap between social classes has tended to widen. This is due to the uncoupling of a section of the working classes (workers), as well as the divide between men and women: $62 \%$ of men said they read very little or not at all, compared with $46 \%$ of women (Donnat 2009).

9. According to Layla Ricroch and Benoît Roumier (2011), "the time that French people spend reading books and newspapers (including online) has decreased by a third since 1986, down to eighteen minutes per day on average in 2010. As a general rule, we can account for the decline in reading literature by the space taken up by mathematics in defining school success and audiovisual media (cinema, television, videos, video games) in the quest for 'entertainment"'. On the notion of "entertainment", see Mauger \& Poliak (1998).

10. According to Claire Bélisle (2011), for example, the decline of the novel seems to give way to developing reading for information and opinion. 
2008b). La question des variations quantitatives des pratiques de lecture soulève celle de leur mesure : quels textes comptabilise-ton dans les pratiques de lecture ? De façon générale, " ceux qui sont désignés comme non-lecteur-rice-s lisent, mais autre chose que ce que le canon scolaire définit comme une lecture légitime »: «De multiples matériaux sont lus par ceux qui déclarent ne jamais lire ", constate Chartier (1997 : 1033-1104) qui fait allusion aux " pratiques infinies, disséminées et multiples qui s'emparent de multiples matériaux imprimés et écrits, tout au long d'une journée ou d'une existence ". Or, la banalisation du numérique induit celle des textes "sans qualités " (des emails aux tweets) ${ }^{11}$, donc aussi celle des « lectures sauvages » (et non comptabilisées) qui s'attachent à ces écrits à faible légitimité culturelle. Cette hypothèse d'une extension des pratiques de lecture induite par la « révolution numérique " conduit également à s'interroger sur leur éventuelle " démocratisation ». Une sociologie des lecteur.rice-s numériques (exclue dans le cadre de l'enquête menée) devrait non seulement mesurer des changements quantitatifs, mais également étudier leur distribution dans l'espace social en fonction des divisions entre les classes, des clivages entre les sexes, des scolarités plus ou moins longues, des maîtrises de la culture écrite plus ou moins assurées, mais sans doute aussi en fonction de l'appartenance à des générations définies par l'apprentissage plus ou moins précoce du support électronique (Donnat 2009) ${ }^{12}$

\section{L'enquête}

Sans pouvoir mesurer les pratiques de lecture, l'enquête se proposait de cerner l'extension des pratiques de lecture, tous textes confondus, de grand·e.s lecteur.rice.s numériques en

11. De façon générale, sans doute assiste-t-on à un revival de la correspondance.

12. Sur les pratiques de lecture numérique des digital natives, voir Octobre (2014). of which texts are included in such reading practices. As a general rule, "those who are designated as non-readers nonetheless read, but the texts are not considered legitimate according to the literary canon": "Various types of texts are read by those who declare that they never read", Chartier concludes (1997: 103-104). He refers to the "infinite, disseminated, multiple practices that seize multiple printed and written materials, during a single day or a whole existence." Yet the widespread use of technology has led to a standardization of "poor quality" texts (from emails to tweets ${ }^{11}$ ), and therefore also of "wild reading" (not included) which is bound up with the lack of cultural legitimacy in these texts. An expansion of reading practices induced by the digital revolution also leads us to question their potential "democratisation." A sociology of digital readers (excluded from the present survey) should not only measure quantitative changes, but also study their distribution in social space according to class division, gender cleavages, shorter or longer periods of schooling, the general mastery of written culture, and should also include generations defined by a relatively early learning process of digital technology (Donnat 2009) ${ }^{12}$.

\section{The Survey}

The survey aimed to determine the extent of reading habits amongst avid digital readers, all texts included, despite its inability to accurately measure reading practices. This was done by asking

11. Generally speaking, we are no doubt also witnessing a revival of letter writing.

12. On the digital reading practices of "digital natives," see October (2014). 
leur demandant de consigner tous les textes lus (articles, billets, documents et livres lus sur support numérique et sur support papier) pendant deux semaines (à la manière de l'enquête emploi du temps de l'Insee). Le dispositif proposé s'est révélé inopérant :

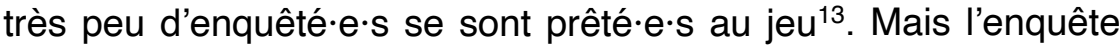
menée se proposait surtout de mettre en évidence, sinon l'apparition d'une « hyperlecture » (Bélisle 2011) ${ }^{14}$, du moins de « nouvelles manières de lire » induites par la « révolution numérique ». Pour les mettre en évidence, le choix d'un échantillon raisonné de diverses catégories de "grand·e·s lecteur-rice-s numériques " se plaçait délibérément dans l'hypothèse la plus favorable à la mise en évidence de changements dans les pratiques de lecture. Réalisée en 2013, l'enquête reposait sur une quarantaine d'entretiens semi-directifs avec des enquêté.e.s qui avaient acquis, en raison de leur activité professionnelle et/ou de leurs pratiques culturelles, une réelle expérience en matière de lecture numérique : " technophiles », "digital natives » âgé·e·s de trente à quarante ans, titulaires de titres universitaires, ils/elles étaient

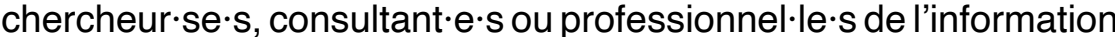
(journalistes et métiers du livre). Les questions posées tentaient de cerner les effets des nouvelles technologies sur leurs pratiques de lecture, en distinguant les lectures d'information au sens large

13. II faudrait pouvoir rendre compte de cet échec : il peut s'expliquer par le caractère trop contraignant de ce dispositif et/ou par son caractère trop intrusif susceptible de révéler un trop grand écart entre pratiques déclarées et pratiques réelles.

14. Dans cette perspective (Bélisle 2011), la technologie numérique favoriserait un autre rapport à l'écrit : elle inviterait le/la lecteur-rice à naviguer dan l'information par le biais des « hyperliens » à l'inverse de la linéarité de la lecture sur papier. La lecture deviendrait ainsi une « hyperlecture » sollicitant les associations, stimulant « la flexibilité cognitive » et la créativité au sein d'un espace partagé démultipliant les dimensions interprétatives, et la lecture numérique s'apparenterait alors à une conversation : lire ne serait plus une pratique solitaire mais " une activité interactive » où cohabitent « marges de manœuvre personnelles » et « dialogue avec l'autre ». participants to make a log of all texts they read (articles, notes, documents and books read on digital and paper mediums) for two weeks (along the lines of INSEE timetable surveys). This measure turned out to be ineffective: very few participants played along ${ }^{13}$. However, the survey mainly aimed to bring out "new reading forms" induced by the digital revolution, despite the difficulty of highlighting the appearance of "hyper-reading" (Bélisle 2011) ${ }^{14}$. Selecting a well-constructed sample of diverse categories of "avid digital reader" seemed the most favourable means of highlighting changes in reading practices to support this hypothesis. The survey was carried out in 2013 and relied on around forty semiprescriptive interviews with participants who had acquired real experience in digital reading through their professional activity and/ or cultural practices. These "technophiles" and "digital natives" are all between thirty and forty years old, have obtained universitylevel degrees and are now researchers, consultants, or media professionals (either journalists or in the book trade). The questions aimed to determine the effects of new technologies on their reading practices-distinguishing reading for information in the wider sense (daily press, professional or scientific documentation) from purely literary reading. More precisely, the aim was to determine potential evolutions in the social uses of reading identified in a previous

13. It should be possible to account for this failure: it can be explained by constraints and/or the intrusive nature of this measure which might indicate an overly obvious disparity between proclaimed and real practices.

14. From this perspective (Bélisle 2011), digital technology would favour another relationship to written texts, inviting the reader to navigate information using "hyperlinks," contrary to the linear character of reading on paper. Reading would thus become a form of "hyper-reading," calling forth associations, stimulating "cognitive flexibility" and creativity in a shared space in which interpretative dimensions proliferate. Digital reading could thus be likened to a conversation: reading would no longer be a solitary activity but rather an "interactive activity," in which "personal room for manœuvre" and "dialogue with the other" would cohabit. 
(presse quotidienne, documentation à caractère professionnel ou scientifique) et les lectures à caractère littéraire. Plus précisément, il s'agissait de mettre en évidence d'éventuelles transformations dans les usages sociaux de la lecture identifiés dans une enquête antérieure : usages de divertissement (" évasion »), d'une part, didactique ou éthique, d'autre part (Mauger \& Poliak 1998) ${ }^{15}$. Un des biais rencontrés dans cette enquête ethnographique fut l'écho trouvé chez les enquêté.e.s par les discours sur la "révolution numérique » et le modernisme technologique : l'appropriation d'une interprétation préconstruite de leurs pratiques leur permettait, en effet, de mettre en scène une représentation d'elles/eux-mêmes comme une sorte d'« avant-garde scientifico-culturelle » qui pouvait masquer le prosaïsme d'une pratique relativement banale et souvent très proche des pratiques de lecture antérieures à usages de divertissement, didactique ou éthique.

L'enquête confirme que les modalités de la pratique de lecture ${ }^{16}$ dépendent plus du genre de texte lu et du type d'usage associé à cette lecture que du support de l'écrit. C'est pourquoi on s'efforcera d'en expliciter les principales conclusions (en les confrontant à celles des travaux disponibles) en étudiant successivement les incidences de la « révolution numérique » sur les lectures à usage de divertissement, puis sur les lectures à usage didactique ou éthique. On s'interrogera, en conclusion, sur un possible déclin de la culture écrite au profit de l'audiovisuel.

15. Soit, lire pour se distraire, lire pour apprendre et lire pour se parfaire (ou s'améliorer). Les usages esthétiques (lire pour le plaisir du texte, « lire pour lire ») étaient exclus du champ d'investigation.

16. En particulier, sa continuité/discontinuité (« lecture séquentielle »/« lecture segmentaire ») (Chartier 2008 : 44). Françoise Benhamou (2014 : 49) évoque une « lecture nomade, axée sur la consultation, séquentielle, fractionnée, prédatrice, cosmopolite, exploratoire». survey: entertainment uses-("escapist") on the one hand; and educational or ethical on the other (Mauger \& Poliak 1998) ${ }^{15}$. One of the biases found in this ethnographic survey was the echo created by the discourse on the digital revolution and technological modernism amongst participants. The preconceived interpretation of their practices indeed allowed them to depict themselves as a sort of "scientific-cultural avant-garde" which could potentially mask the everyday occurrence of a relatively banal practice, often very close to the former habits of reading for entertainment, educational, or ethical purposes.

The survey confirmed that reading practice methods ${ }^{16}$ depend more on the genre of text and the type of reading associated with it than on the medium used. We will thus clarify the main conclusions (and compare them to available studies) by studying the impact of the digital revolution on reading for entertainment, followed by educational or ethical purposes. We will then conclude with a reflection on the potential decline of written culture in favour of audiovisual media.

15. I.e., reading for entertainment, reading for learning or personal development purposes. Aesthetic uses (reading for pleasure, "reading for readings' sake") were excluded from the field of investigation.

16. Above all, its continuity/discontinuity ("sequential reading"/"segmented reading") (Chartier 2008: 44). Francoise Benhamou (2014: 49) evokes a "nomadic reading, centred on consultation, sequential, fractioned, predatory, cosmopolitan, exploratory." 


\section{3. «Révolution numérique » et lectures de divertissement}

La révolution des pratiques de lecture en matière littéraire annoncée par les exégètes les plus enthousiastes ne semble pas avoir eu lieu. L'enquête menée auprès de grand·e.s lecteur.rice.s de romans montre que le roman et l'usage de « divertissement » qui lui est associé, se prêtent mal, quel que soit le support de l'écrit, à une lecture trop discontinue. La " lecture segmentée » ne s'est pas substituée à la « lecture dense ». Pour l'essentiel, les incidences de la « révolution numérique » en ce qui concerne la lecture de romans se résument à la perception des potentialités techniques et pratiques offertes par les nouvelles technologies (liseuses)

\subsection{Lecture dense/segmentée}

Qu'advient-il de la " lecture dense " associée aux textes à usage de divertissement (ou d'évasion) sur support papier ? Converti avant la « révolution numérique » à la « lecture segmentée », Hans Magnus Enzensberger revendiquait « le droit de feuilleter le livre d'un bout à l'autre, d'en sauter des passages entiers, de lire les phrases tout de travers, de les déformer, de les recomposer, de les entrelacer et de les améliorer de toutes sortes d'associations, d'en tirer des conclusions que le texte ignore, d'enrager ou de se réjouir à sa lecture, de l'oublier, d'en faire un plagiat, et même de jeter le livre dans un coin ${ }^{17}$ ». Cette " lecture postmoderne » se présente, selon Armando Petrucci (1997 : 417-418), « comme "anarchique, égoïste, égocentrique", reposant sur un unique impératif : "Je lis ce que je veux" ", revendique le droit de ne pas être "snob ", de refuser légitimement tout conditionnement, toute recommandation extérieure, l'objectif de « simple divertissement » et une conception du livre comme « objet d'usage immédiat, à consommer et à perdre

17. Cité par Armando Petrucci (1997 : 423).

\section{The "Digital Revolution" and Reading for Entertainment}

The revolution of literary reading habits predicted by the most ardent exegetes does not seem to have taken place. The survey results amongst avid novel readers show that reading for "entertainment" associated with novels does not lend itself, regardless of the medium, to discontinuous reading behaviour. "Segmented reading" has not superseded "dense reading." For the most part, the effects of the digital revolution regarding reading novels amount to an understanding of technical and practical possibilities offered by new technology (e-readers).

\subsection{Dense/Segmented Reading}

What happens to the "dense reading" associated with texts for entertainment (or escapist) purposes on paper? Hans Magnus Enzenberger converted to "segmented reading" before the "digital revolution." He asserted "the right to skim read the book from beginning to end, to skip whole passages, to read sentences askew, to deform and recompose them, to interlace and improve them with all sorts of associations, to conclude that which the text ignores, to get mad and rejoice while reading, to forget, plagiarize and even to throw the book in a corner ${ }^{17}$." According to Armando Petrucci (1997: 417-418), this "postmodern reading" is "anarchic, egotistical, egocentric," and rests on a single imperative: "I read what I want" asserts the right to not be a "snob" to legitimately reject all conditioning, all exterior recommendations, the aim of "pure entertainment," and a perception of books as "objects for immediate

17. Cited by Armando Petrucci (1997: 423) 
voire à jeter à peine lu »18. À l'encontre de ce genre d'iconoclasme, l'enquête menée met surtout en évidence la continuité des modalités de la pratique indépendamment du support. Ne serait-ce d'ailleurs que parce que les livres numériques sont, comme le rappelle Françoise Benhamou (2009), « d'authentiques livres, versions numériques d'ouvrages qui sont en général édités et diffusés sous forme imprimée ${ }^{19}$. C'est aussi la raison pour laquelle, la liseuse, apparue dans les années 1990, est le support privilégié (en dehors du support papier) de la lecture de textes longs et, en particulier, d'œuvres littéraires ${ }^{20}$ : ses autres fonctions éventuelles (navigateur Internet, par exemple) restent secondaires et sont rarement mentionnées par les enquêté·e.s. Par son caractère

18. Dans la même perspective, selon Raffele Simone (2012 : 25, 172), " la médiasphère fait prévaloir le papillonnage sur la concentration, la fragmentation sur la continuité » et « la navigation en ligne - sauf si elle est guidée par un contrôle inflexible des objectifs poursuivis - n'est à proprement parler qu'une manière de se perdre dans le cyberespace ".

19. Si les livres numériques peuvent " comporter des "plus" par rapport à la version imprimée, comme des liens hypertextes ou des vidéos incrustées, [ils] demeurent des livres, avec un début et une fin malgré quelques expériences très marginales encore de littératures hypertextuelles, en tout cas des œuvres cohérentes et achevées d'un auteur ou d'un collectif d'auteurs et fruits d'un travail éditorial complet sur le fond et sur la forme » (Benhamou, 2009).

20. Comme avec l'apparition du livre de poche, on peut s'interroger sur les incidences de la baisse des prix (sinon de la gratuité) associée au numérique sur les pratiques de lecture. Toutefois, si la lecture sur fichiers numériques a atteint $27 \%$ aux États-Unis en 2013 et $17 \%$ en Grande-Bretagne, elle n'est que de $2 \%$ en France (Mollier 2014). Selon Françoise Benhamou (2014 19), le livre numérique représente $3 \%$ du chiffre d'affaires en Italie et en France et 4 à $5 \%$ des ventes en exemplaires. Selon Hervé Bienvault (2012), « ce sont les lecteurs de mass-market paper backs (livres de poche de basse qualité) qui ont commencé à adopter le Kindle, une clientèle de gros lecteurs qui ne souhaitent pas forcément conserver les livres qu'ils lisent. Les secteurs de la littérature sentimentale, science-fiction, fantasy, polar, thriller sont les plus concernés, les plus plébiscités dans l'univers numérique ». use, to be consumed and lost, even thrown away, barely read ${ }^{18 . "}$ Faced with this kind of iconoclasm, the survey mainly highlights the continuity of which methods are preferred, regardless of medium. This could be precisely because digital books are, as Françoise Benhamou (2009) reminds us, "authentic books, digital versions of works that are usually edited and distributed in printed form ${ }^{19}$." This is also why the e-reader, which emerged in the 1990s, is the preferred medium (besides paper) for reading long texts and above all literary works ${ }^{20}$. Its other potential functions (internet browsing, for instance) remain secondary and are rarely mentioned by the survey participants. Due to its mono-task nature, the e-reader substitutes other digital devices: its limited functionality enables the break necessary for intensive reading.

18. From the same perspective, according to Raffele Simone (2012: 25 172), "in the media sphere, flitting from one thing to the next prevails over concentration, fragmentation over continuity" and "online browsing-unless firmly guided by a specific aim -is solely a way of getting lost in cyberspace".

19. Although digital books "contain 'extras' compared with the printed version, such as hypertext links or embedded videos, [they] nonetheless remain books, with a beginning and an ending (despite a still very rare amount of hypertextual literature), in any case they are coherent and finished works by an author or author collective and the result of thorough editorial work, in terms of content as well as form" (Benhamou 2009).

20. Just as when the paperback appeared, we can reflect upon the impact of the digital-related decrease in prices (to the point of books sometimes becoming free) on reading habits. Nevertheless, while reading on digital files reached $27 \%$ in the United States in 2013 and 17\% in Great Britain, it only reached 2\% in France (Mollier 2014). According to Françoise Benhamou (2014: 19), digital books represent $3 \%$ of sales revenue in Italy and France, and $4-5 \%$ of copy sales. According to Hervé Bienvault (2012), "the readers of massmarket paperbacks are the ones who started to use the Kindle, a clientele of avid readers who did not necessarily want to keep the books they read. Romance novels, science fiction, fantasy, crime, and thrillers are the sectors of the market that are concerned the most and have the most ardent support from the digital world." 
mono-tâche, elle se substitue aux autres appareils numériques : ses fonctionnalités limitées favorisent cette coupure nécessaire à

la lecture intensive.

«Moi, j'aime bien la liseuse parce que j'aime bien déconnecter d'internet et de tout ça. C'est pour ça que mes romans, je les lis principalement sur liseuse. Après, si je veux sortir de ma lecture, je sais que je ne serai pas tenté par internet. " (Alban W., 22 ans, étudiant, équipé d'une liseuse.)

Reste qu'il va de soi qu'« intensive » ou « extensive », « rapide » ou « dense », la pratique de lecture dépend évidemment du/de la lecteur-rice, du texte lu et de l'usage attendu (ces modalités distinctes de la lecture étant d'ailleurs susceptibles de cohabiter chez un·e même lecteur·rice indépendamment du support).

\subsection{Agréments et inconvénients de l'écrit numérique}

En fait, l'enquête permet surtout d'établir un inventaire prosaïque des agréments et des inconvénients que les grand·e.s lecteur·rice·s attribuent au texte numérique.

La numérisation des textes permet leur acquisition instantanée (et, dans certains cas, un accès gratuit) :

« C'est pratique parce qu'on peut acheter le livre dans la minute qui suit l'idée de l'acheter et on l'a chez soi. » (Jacqueline O., 65 ans, médecin retraitée, équipée d'une liseuse.)

La liseuse a également des capacités de stockage (et de transport) quasi illimitées sans encombrement : nouvelle forme de capital culturel objectivé, « la bibliothèque numérique » n'occupe pas d'autre espace que celui de l'écran.
"I like using e-readers because I like cutting off from the internet and all that. That's why I mainly read my novels on e-readers. Even if I want to stop reading, I won't be tempted to surf the net." (Alban W., 22 years old, student, owns an e-reader.)

It goes without saying that whether "intensive" or "extensive," "fast" or "dense," reading habits obviously depend on the reader, the text, and its expected use (these different means of reading are moreover likely to manifest in the same reader, regardless of medium).

\subsection{Advantages and Disadvantages of Digital Writing}

In fact, the survey mainly enables us to establish a prosaic inventory of the advantages and disadvantages that avid readers ascribe to digital texts.

The digitalisation of texts enables their instant acquisition (and in some cases, free access):

"It's practical because you can buy a book the same minute you think of buying it, and instantly have it at home." (Jacqueline O., 65 years old, retired doctor, owns an e-reader.)

E-readers also have unlimited storage (and transport) capacity: a new form of objectified cultural capital, the "digital library" does not take up any more space than the screen itself. 
" Maintenant, je vis dans un appartement qui est relativement petit, donc... je ne peux pas entasser à l'infini. Donc ça, c'est une aubaine... » (Jacqueline O., 65 ans, médecin retraitée, équipée d'une liseuse.)

« C'est très léger, ça prend pas beaucoup de place. E comme j'ai tendance à pas mal bouger, surtout dans Paris pour le boulot... On glisse ça, on a un énorme choix... » (Pierre W., 32 ans, professeur, équipé d'une liseuse.)

"C'est aussi le fait que dans un truc très petit vous avez plusieurs centaines de bouquins donc bon... Du point de vue du transport, c'est imbattable ! Parce que les œuvres sont dématérialisées, elles ne sont même pas sur la machine, vous pouvez les avoir sur Internet. 》 (Claude D., 65 ans, ingénieur d'études retraité, équipé d'une liseuse.)

La liseuse permet également d'adapter la taille des caractères à la vue du/de la lecteur-rice

"L'autre chose que j'ai appréciée, c'est que nos yeux se fatiguent quand on vieillit et le simple fait de pouvoir ajuster la taille des caractères au niveau convenable pour pas se fatiguer en lisant, pour moi, c'est un vrai plus. Finalement, s'il fallait dire pourquoi parfois je préfère un livre numérique à un livre papier, c'est ça, c'est pouvoir agrandir la taille des caractères. Je pense qu'à la fin de ma vie, je finirai en ne lisant que des livres numériques. " (Claude D., 65 ans, ingénieur d'études retraité, équipé d'une liseuse.)

Enfin, entre les ouvrages tombés dans le domaine public, les promotions des diffuseurs de livres numériques, les auto-éditions et les livres numériques « craqués », l'offre de littérature gratuite ou quasi gratuite est devenue illimitée, ouvrant ainsi l'opportunité d'une accumulation sans encombrement matériel de biens culturels. Nombre de grand·e·s lecteur-rice·s ont ainsi commencé à télécharger parfois plusieurs milliers d'ouvrages sur leur liseuse :
"I now live in a flat that is quite small, so... I can't keep piling books up infinitely. So, this is a blessing..." (Jacqueline O., 65 years old, retired doctor, owns an e-reader.)

"It's very light; it doesn't take up much space. And since I move around a lot, especially around Paris for work... you just slip it in your pocket, and there is so much choice..." (Pierre W., 32 years old, teacher, owns an e-reader.)

"It's also a fact that you can have hundreds of books on a very small thing... From a transport point of view, it's unbeatable! Since the books are electronic, they aren't even on the machine, you can have them on the internet." (Claude, 65 years old, retired engineer, owns an e-reader.)

\section{E-readers also allow readers to adapt the font size to their eyesight:}

"The other thing that I appreciated is that our eyes get tired when we grow older, and the simple fact of being able to adjust to a more convenient font size so as not to tire my eyes out is a real selling point for me. If I had to say why I prefer e-books to paper books, it's because I can adjust the font size. I think that towards the end of my life, I will end up only reading e-books." (Claude D., 65 years old, retired engineer, owns an e-reader.)

Finally, given the books that are already in the public domain, promotions by distributors of electronic readers, self-published books and "hacked" digital books, the literature available that is free or almost-free has become unlimited, thus opening up the possibility of collecting them without necessarily hoarding cultural goods. Many avid readers have thus started to download many thousands of books onto their e-readers: 
" J'ai une bibliothèque numérique avec plus de dix mille bouquins. Je me suis demandé si ce n'était pas une accumulation, un stade anal mal vécu... Je sais que je ne lirai jamais dix mille livres, mais j'ai vraiment la possibilité de lire un bouquin qui correspond exactement à mon mood du moment, un de SF, un roman nordique, un classique... J'ai aussi créé un répertoire à lire mais tout le monde a ça aussi. Et là, j'ai mis des trucs qui ne font pas partie de mes lectures habituelles, mais qui avaient l'air vraiment bien, de temps en temps je jette un œil. » (Charles S., 62 ans, chercheur en sciences sociales retraité, équipé d'une liseuse.)

"À première vue, c'est formidable, mais c'est presque un peu trop, on se noie là-dedans, je ne pense pas que je lirai tout ça. Mais c'est réjouissant de savoir que je peux avoir tout ça sous la main, en plus gratuit quand même, ça c'est extraordinaire. » (Arlette H., 70 ans, cadre administrative retraitée, équipée d'une liseuse.)

C'est ainsi que l'acquisition d'une liseuse numérique et la possibilité de télécharger simplement et gratuitement l'ensemble des œuvres tombées dans le domaine public favorise les velléités

$$
\text { de « rattrapage culturel ». }
$$

« Je suis contente parce que j'ai beaucoup de classiques j'ai tout Anatole France, j'ai tout Dumas, j'ai Colette, j'ai Balzac. Même si j'ai pas lu Balzac, j'ai lu un tout petit peu et ça me plaît bien. Je suis quand même contente de les avoir. Je suis un peu compulsive. J'aime les avoir. Même si je les ai pas lus. Je suis contente de pouvoir me dire que je les lirai un jour. » (Mélissa A., 40 ans, informaticienne, équipée d'une tablette et d'une liseuse.)

« J'ai téléchargé tous les classiques que j'ai toujours regretté de ne pas avoir lus ou à peine entrouverts, c'est l'occasion de s'y remettre et c'est pour ça que j'ai pris Proust, Zola, j'ai pris Dostoïevski, je sais plus... [...] Alors j'ai pas
"I have a digital library with more than 10,000 books in it. I wondered whether this is a kind of hoarding, an unresolved obsession... I know that I will never read 10,000 books, but I truly have the option of reading a book that always corresponds exactly to my mood, a Science Fiction book, a Nordic book, a classic... I also made a "to read" folder, but everyone has that. And now l've downloaded things I wouldn't usually read, but which looked really good, so from time to time I have a look." (Charles S., 62 years old, retired social scientist, owns an e-reader.)

"At first sight it seems wonderful, even a bit too much, one could drown in it-I can't possibly read all of that. But it's good to know that I have all of this at my disposal, for free, it's extraordinary." (Arlette H., 70 years old, retired administration executive, owns an e-reader.)

Thus, owning an e-reader and the possibility of easily downloading all public domain books for free allows for a kind of "cultural catching up."

"I am happy to have a lot of classics: I have all of Anatole France, all of Dumas, I have Colette, Balzac. Even though I haven't read Balzac, I've read a tiny bit and I like it. I'm still happy to have them. I am a bit compulsive. I like to have them. Even if I haven't read them. I am happy to be able to tell myself that I may read them one day." (Melissa A., 40 years old, computer scientist, owns a tablet and an e-reader.)

"I downloaded all the classics that I had always regretted not having read or at least looked into. This is the time to get back to it, so I got Proust, Zola, Dostoevsky, I can't remember what else... [...] I haven't re-read anything yet; I started reading Proust again, well actually I started it, I hadn't read 
relu encore, Proust j'ai recommencé, enfin j'ai commencé, je n'avais pas lu grand-chose avant. " (Arlette H., 70 ans, cadre administrative retraitée, équipée d'une liseuse.)

Côté inconvénients, outre que la lecture numérique confronte à l'absence du repérage associé à l'épaisseur du livre imprimé - on découvre que "l'épaisseur était une dimension de l'œuvre littéraire »(Bon, 2011 : 26) (permettant, par exemple, d'évaluer implicitement la « distance » qui sépare la lecture en cours du dénouement) -, une bibliothèque numérique, si étendue soit-elle, ne se prête guère à la mise en scène et à la vision synoptique du capital culturel accumulé sous sa forme objectivée. En fait, il semble que l'écrit numérique n'ait jamais la valeur accordée aux textes imprimés dans la mise en scène de l'habitat (et de l'habitus) :

« Potentiellement, vous en avez plus parce que les œuvres sont dématérialisées. En revanche, ça n'a pas le côté décoratif d'une étagère remplie de livres triée par auteurs, voilà... » (Claude D., 65 ans, ingénieur d'études retraité, équipé d'une liseuse.)

« J'ai une petite bibliothèque. De toute façon, j'ai toujours gardé ce que je préférais, il y a déjà eu une sélection qui a été faite. II y a des fois où j'avais le bouquin en papier et j'ai acheté la version numérique pour ne pas avoir à me trimballer mon bouquin. Je dis ça parce qu'il est mis en scène chez moi, avec la couverture devant. II y a d'autres choses qui sont mises en scène, comme mes guides de voyage, tous de la même collection. II y a des villes dans lesquelles je suis allée, des collections de DVD qu'il faudrait que je vende ou donne. Mais j'ai du mal à m'en séparer. » (Anna L., 28 ans, consultante, équipée d'une liseuse.) much before." (Arlette $\mathrm{H}$., 70 years old, retired administration executive, owns an e-reader.)

Faced with the immediate lack of bearings compared with a printed book, digital reading raises the fact that "size was a factor of literary works" (Bon 2011: 26) (which, for instance, allowed the reader to implicitly evaluate the "distance" separating the passage being read from the ending). Yet digital libraries, however large, hardly lend themselves to being on display and to a synoptic visioning of accumulated cultural capital in its objectified form. In fact, it seems that digital writing will never have the value bestowed upon printed texts displayed at home (and the habitus):

"You can even have so many more, because the books are dematerialized. However, it doesn't have that decorative touch that a full, alphabetically ordered bookshelf has..." (Claude D., 65 years old, retired engineer, owns an e-reader.)

"I have a small library. Anyway, I've always kept my favourites, l've already culled them. Sometimes I had the paper book and I bought the digital version so as to not have to carry the book around. I say that because it is on show at home, with the cover page in front. Other books are also on show, like my travel guides, all from the same collection. There are towns I have been to, DVD collections that I should sell or give away. But I find it difficult to get rid of it all." (Anna L., 28 years old, consultant, owns an e-reader.) 


\section{4. «Révolution numérique » et lectures didactiques ou éthiques}

Si la télévision reste, loin devant la presse papier et la radio, la principale source d'information pour $50 \%$ des Français·es, la diffusion massive du Web haut-débit modifie la diffusion et la réception de l'information : entre 1973 et 2008, les lecteur.rice-s régulier-ère-s de la presse quotidienne passent de 55 à $29 \%$, la part des lecteur.rice.s irrégulier ère-s de 22 à $40 \%$ et celle des «nonlecteur.rice.s » de 23 à $29 \%$. En 2012, 20,6 millions de Français·es consultent la presse numérique sur mobile ou sur tablette (Le Floch \& Sonnac 2013), notamment les moins de 35 ans pour lesquels il s'agit de la deuxième source d'information (Donnat 2009) ${ }^{21}$. Dans le cadre de l'enquête menée, rares sont celles et ceux qui achètent encore un quotidien, alors que la quasi totalité des enquêté $\cdot e \cdot s$ lit quotidiennement la presse sur internet. Ils utilisent internet pour s'informer et diversifient leurs sources d'information (Granjon \& Le Foulgoc 2010). À l'inverse des lectures littéraires, la lecture de la presse ou de livres pratiques (Defrance 1996), à usages " didactiques » et/ou « éthiques », peut s'accommoder d'une « lecture segmentée » (zapping), sinon y inciter.

\subsection{Une lecture segmentée ?}

Selon Armando Petrucci (1997: 420), la « culture audiovisuelle » aurait inculqué la pratique du zapping : « Le zapping, écrit-il, est un instrument individuel de consommation et de création audiovisuelles absolument nouveau. À travers lui, le consommateur de culture médiatique s'est habitué à recevoir un message composé de fragments non homogènes, et surtout, privé de "sens". [...] Cette

21. De façon générale, la lecture d'informations politiques sur internet est essentiellement le fait des jeunes générations (digital natives) et des catégories les plus diplômées qui associent plusieurs médias : presse papier, Internet, radio, etc. (Le Hay, Vedel, Chanvril 2011).

\section{The "Digital Revolution" and Educational or Ethical Readings}

Although the television remains far ahead of the printed press and radio as the number one information source for $50 \%$ of all French citizens, mass high-speed internet has changed how information is disseminated and obtained. Between 1973 and 2008, the number of readers of daily newspapers went from $55 \%$ to $29 \%$, irregular readers went from $22 \%$ to $40 \%$, and "non-readers" increased from $23 \%$ to $29 \%$. In 2012, 20.6 million French people consulted the digital press on their phone or tablet (Le Floch \& Sonnac 2013), especially under-35 years old for whom it constitutes the second most used source of information (Donnat 2009) ${ }^{21}$. In the context of the survey, very few admitted to buying daily papers, and nearly all of those interviewed read the press on the internet every day. They use the internet to get information and diversify their sources (Granjon \& Le Foulgoc 2010). Unlike the reading of literature, reading newspapers and practical guides (Defrance 1996) for "educational" and/or "ethical" purposes allows for "segmented reading" (hereafter referred to as "zapping"), and may even encourage it.

\subsection{Segmented Reading?}

According to Armando Petrucci (1997: 420), "audio-visual culture" inculcated "zapping" practices: "Zapping is an entirely new individual consumerist and creative audio-visual device. Through it, the media culture consumer has gotten used to receiving a message composed of non-homogenous fragments, devoid of 'meaning.' [...] This ever-more current media habit is exactly the opposite of reading, understood in the traditional sense-i.e. linear

21. Political news is generally read on the internet by younger generations ("digital natives") and by more educated groups who combine multiple media forms: newspapers, internet, radio, etc. (Le Hay, Vedel, Chanvril 2011). 
pratique médiatique de plus en plus répandue est exactement le contraire de la lecture entendue dans son sens traditionnel, linéaire et progressive, mais elle se rapproche de la lecture transversale, cavalière, interrompue, tantôt lente, tantôt rapide, qui est celle des lecteurs déculturés. [...] La pratique du zapping et les feuilletons télévisés qui durent depuis plusieurs années ont forgé des lecteurs potentiels qui non seulement sont dépourvus de "canon" et d"'ordre de la lecture", mais qui n'ont pas non plus acquis le respect, traditionnel chez le lecteur de livres, de l'ordre du texte, lequel comporte un début et une fin et doit donc être lu selon une séquence précise établie par d'autres ${ }^{22}$."

De même, selon Maryanne Wolf (2008), psychologue et neurologue, " avec le numérique, on scanne, on navigue, on rebondit, on repère. Nous avons tendance à bouger, à cliquer et cela réduit notre attention profonde, notre capacité à avoir une lecture concentrée. Nous avons tendance à porter plus d'attention à l'image. Nous avons tendance à moins internaliser la connaissance et à plus dépendre de sources extérieures ». Ces craintes sont sans doute d'autant plus vives qu'elles opposent la lecture numérique à une vision idéalisée de la lecture sur papier (Mauger 1992) et qu'elles comparent, sans le dire, la lecture de textes différents.

Quand ils évoquent leurs pratiques de lecture de l'actualité sur le Web, les enquêté·e·s parlent, en effet, de « scanner rapidement les

22. Dans la même perspective, Raffaele Simone (2012: 60) écrit : « À la fin $\mathrm{du} \mathrm{XX}^{\mathrm{e}}$ siècle, nous sommes graduellement passés d'une situation ou la connaissance complexe ne s'acquérait qu'à travers le livre et l'écriture (c'est-à-dire par l'intermédiaire de l'œil et de la vision alphabétique ou, s l'on préfère, de l'intelligence séquentielle) à une situation où l'on acquiert aussi - et pour certains de manière essentielle - par l'ouïe (c'est-à-dire par l'oreille) ou la vision non alphabétique (qui est une modalité spécifique de l'œil) ». and progressive. It is much closer to transversal, nonchalant, interrupted, oscillating between slow and fast reading, which is a style found amongst uncultured readers. [...] Zapping habits and television series that have been going on for years have created potential readers who not only are deprived of a 'canon' and 'reading order', but have also not acquired the book-readers' traditional respect of a book's order, which has a beginning and an end and must thus be read in a precise sequence pre-established by others $22 . "$

Similarly, according to Maryanne Wolf (2008), a psychologist and neurologist, "in the digital dimension, we scan, browse, bounce off things, bookmark. We tend to move and click around and that reduces our deep attention, our capacity to be concentrated while reading. We tend to focus more on images. We internalize knowledge less and depend on exterior sources more." These fears are all the more acute in that they contrast an idealized vision of reading on paper with digital reading (Mauger 1992). Furthermore, they implicitly compare reading different kinds of text.

When they evoked their reading habits of online news, the participants of the survey indeed mentioned "scanning articles quickly," "skim reading," and "glancing over headlines."

22. In the same vein, Raffaele Simone (2012: 60) writes: "Toward the end of the 20th Century, we have gradually gone from a situation where knowledge is complex and could only be gained through books and writing (i.e. through the eye and alphabetical vision, or sequential intelligence) to a situation where we can also acquire knowledge-for some almost entirely-through hearing (i.e. using auditory faculties) or non alphabetical vision (a faculty specific to the eye)." 
articles », de « balayer du regard », de « jeter un coup d'œil sur les gros titres ».

«On ne lit pas de la même façon, on lit en diagonale, on a tendance à surfer, à naviguer d'un sujet à l'autre. On lit un truc qui nous intéresse, mais il y a un mot qui clignote et on a tendance à aller vers les mots qui clignotent ! On est attiré par ça. Effectivement, j'ai peut-être besoin d'avoir la version papier pour avoir le sentiment de lire des articles de fond alors que sur le net, j'ai tendance à surfer sans avoir une lecture maintenue. » (Vanessa H., graphiste, 40 ans, équipée en tablette et liseuse.)

Mais l'enquête montre surtout que le support numérique conduit à diversifier les sources d'informations:

«Dans la journée, je vais très régulièrement sur tous les sites des médias. J'ai un rituel, j'arrive le matin, j'ouvre ma boite mail pro, ma boite mail perso, Facebook que je consulte rapidement et ensuite je fais dans l'ordre : Libé, Le Figaro, Le Parisien, Le Monde, Le Nouvel Obs', Rue89, 20 Minutes, Métro ${ }^{23}$. » (Julien N., collaborateur d'élu, 38 ans, équipé d'une tablette, lecteur professionnel en raison de son activité.)

« Je suis un peu un "information junkie". Je lis la presse tous les matins, je lis trois quotidiens au minimum, voire plus. Je lis les titres, les flux RSS et je lis en diagonale, je papillonne. J'aime bien avoir ce tour d'horizon de haut. J'ai une série de flux RSS à différents niveaux, sur l'iPhone, sur le Mac. » (Benjamin W., développeur de logiciels, 56 ans, équipé d'une tablette, technophile averti.)

23. II s'agit de quelques-uns des principaux titres de la presse quotidienne française.
"You don't read in the same way, you read diagonally, surfing and browsing from one topic to the next. You read something that interests you, but a word flashes and we tend to go towards flashing words! We're attracted to that. I maybe need the paper version to feel like I'm really reading in-depth articles, whereas on the net I tend to surf without indepth reading." (Vanessa $H_{\text {. }}, 40$ years old, graphic designer, owns a tablet and an e-reader.)

But the survey mainly demonstrates that the digital medium leads to multiple information sources:

"Throughout the course of a day, I regularly go onto all media websites. I have this ritual, I arrive in the morning, I open up my work mailbox, my personal mailbox, I take a quick look at Facebook and then I go onto: Libé, Le Figaro, Le Parisien, Le Monde, Le Nouvel Obs', Rue 89, 20 Minutes, Métro, in that order ${ }^{23}$." (Julien N., 38 years old, political advisor, owns a tablet and a professional e-reader for his work.)

"I am a bit of an information junkie. I read the press every morning, I read at least three daily papers, if not more. I read the title, the RSS feeds and I read diagonally, I flit from one thing to the next. I like getting a general view. I have a series of RSS feeds on various levels on my iPhone and my Mac." (Benjamin W., 56 years old, software developer, owns a tablet, self-proclaimed technophile.)

23. These are some of the main daily French newspapers 
S'il est vrai que la diversification, le tri, la sélection des sources d'informations, le croisement des opinions et des points de vue, pour "se faire une opinion " aussi autonome que possible par rapport aux médias, est une pratique distinctive des détenteurs d'un capital culturel élevé, on peut supposer que l'usage d'internet, par la possibilité inédite qu'il offre d'accéder gratuitement, rapidement et parfois même involontairement (via des liens hypertextes), à un très grand nombre de titres, a banalisé cette pratique et l'a consolidée chez les ancien·ne·s pratiquant·e.s. L'enquête montre que le libre accès à un vaste répertoire de la presse nationale et étrangère autorise le/la lecteur-rice sur écran à improviser sa " revue de presse » et, ce faisant, à cultiver l'illusion d'avoir «l'objectivité à portée de main »:

« Je crois que la lecture transversale sur Internet a du sens et qu'elle permet d'avoir une vision plus panoramique des choses et plus personnelle, on choisit un peu ses sources d'information et on fait le tri. Le système d'abonnement sur Internet je pense que c'est une connerie, c'est fini, il faut trouver autre chose. [...] II y a eu des périodes où j'étais abonné au Monde, à L'Huma. Je pense que l'abonnement c'est une forme de polarisation de la source informationnelle qui aujourd'hui n'a plus lieu d'être, je crois qu'au contraire aujourd'hui on a un intérêt majeur à multiplier les sources. » (Benjamin W., développeur de logiciels, 56 ans, équipé d'une tablette.)

" On achète Le Figaro parce qu'on est à droite, on se renforce dans ses idées mais du coup on n'apprend rien, quoi. On ne parle à personne. Internet, au contraire, c'est plus varié. Moi je me fais ma propre ligne éditoriale. »

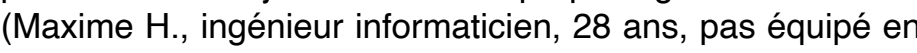
tablette et liseuse.)

" II y a deux catégories de journaux, on va dire, il y a ceux que je lis parce qu'il faut savoir ce que l'ennemi dit et il
Diversification, sorting, information source selection and opinion and viewpoint cross-checking in order to "form one's own opinion" as independently of the media as possible is arguably a practice specific to those with high cultural capital. If so, we can suppose that internet use, with its novel possibility of free, fast, and sometimes involuntary access (through hypertext links) to a large number of titles, has trivialized this practice and consolidated it amongst older practitioners. The survey demonstrates that free access to a vast repository of national and foreign press enables on-screen readers to improvise their own press review and, in doing so, cultivate the illusion of "on-hand objectivity":

"I think that transversal online reading makes sense and allows for a more panoramic and personal vision, we kind of choose our information sources and sort through them. Online subscription systems are bloody stupid, I think we have to find something else. [...] I used to have subscriptions for $L e$ Monde and L'Huma. I think that subscriptions encourage a polarizing of information sources which doesn't make much sense today. On the contrary, I think that nowadays we need to expand our [information] sources." (Benjamin W., 56 years old, software developer, owns a tablet.)

"People buy Le Figaro because they're right wing; their ideas are affirmed but they don't really learn anything new. They don't talk to anyone. The internet, on the other hand, is more varied. I get to make my own editorial line." (Maxime $\mathrm{H}$., 28 years old, information engineer, does not own a tablet or e-reader.)

"Let's say there are two types of newspaper. There are those I read because I need to know what the enemy is saying and there are those I read because I find them interesting. So, the enemy, for me, is Le Monde, Libé, the 
y a ceux que je lis parce que je trouve ça intéressant. Donc l'ennemi pour moi c'est Le Monde, c'est Libé, c'est toute la presse mainstream. II faut que je sache ce que les gens disent et pourquoi. Et après, il y a ce qui m'intéresse vraiment moi, donc ce sera Le Monde diplo, Acrimed, le CADTM²... des trucs de gaucho, hein ! » (Thierry $\mathrm{H}$., fonctionnaire des impôts, 32 ans, non équipé en tablette et liseuse.)

Faut-il alors considérer que cette lecture « segmentée », discontinue, attachée au fragment plus qu'à la totalité », apparentée au «braconnage » selon Michel de Certeau (1990), marque une rupture par rapport aux pratiques de lecture antérieures à la « révolution numérique » ? Selon Chartier (2008:21), « on voit mal en quoi elle se distingue nécessairement de la lecture de codex » qui, note-t-il, « invite à feuilleter les textes [...], à comparer différents passages [...], à extraire et copier citations et sentences $»^{25}$. En fait, la « lecture segmentée » en matière d'information (usages didactiques), supposée propre à l'ère du zapping numérique, s'apparente plus à la reconduction (et peut-être l'extension) d'une pratique antérieure qu'à une pratique inédite. Au début de l'ère moderne, en un temps où lecture et écriture étaient inséparables et où le recueil de citations atteignit son apogée à la fin de la Renaissance (Darnton 2011 : 21-45), les Anglais « lisaient par à-coups et sautaient d'un livre à l'autre », « à la différence des lecteurs modernes, qui suivent le mouvement d'un récit du début à la fin (sauf s'ils sont nés avec le numérique et cliquent à travers les

textes sur des machines) ».

24. II s'agit de quelques titres de presse ou de sites de la « gauche critique » en France.

25. Toutefois, la lecture numérique ne perçoit pas immédiatement « les limites et la cohérence du corpus dont ils sont des extraits » (Chartier $2008: 21-22$ ). mainstream press. I need to know what people are saying and why. I'm really interested in Le Monde diplo, Acrimed, CADTM... basically, left-wing newspapers! 24" (Thierry H., 32 years old, tax officer, does not own a tablet or e-reader.)

Must we then consider this "segmented," discontinuous readingwhich is more attached to the fragment than its totality and that Michel de Certeau (1984) likens to "poaching"-as marking a rupture with reading habits before the digital revolution? According to Chartier (2008: 21), "it is hard to see how it is necessarily distinguished from codex reading" which, he notes, "invites the reader to leaf through texts [...], compare passages [...], extract and copy citations and sentences ${ }^{25}$." In fact, "segmented reading" in information terms (educational purposes), supposedly specific to digital "zapping", can be better described as the renewal (and maybe extension) of a previous rather than an unprecedented practice. At the start of the modern era, when reading and writing were inseparable and quotation collections reached their height at the end of the Renaissance (Darnton 2011: 21-45), the English "read erratically and jumped from one book to the next," "unlike modern readers, who follow a story from beginning to end (except for those born in the digital world, who click through text on machines)."

24. These are some of the main newspapers or websites of the French "critical left."

25. Nonetheless, digital reading does not immediately perceive "the limits and coherence of the corpus from which these sentences are extracted"(Chartier 2008: 21-22). 
De même, en ce qui concerne la lecture à usage exclusivement didactique d'ouvrages scientifiques, il semble que la forme numérique encourage, plus qu'elle n'invente, la lecture à plusieurs niveaux que Darnton $(2011: 175)$ associe aux « hypertextes » : elle " inciterait à un genre nouveau de lecture, écrit-il, certains lecteurs se contentant d'un rapide parcours du récit supérieur, d'autres désirant lire verticalement et suivre certains thèmes de plus en plus profondément dans la documentation et les essais complémentaires. Un troisième groupe de lecteurs naviguerait dans des directions inattendues en quête de connexions qui répondent à leurs propres intérêts ou remanierait les matériaux pour les organiser à leur façon. [...] L'écran d'ordinateur serait utilisé pour sélectionner et chercher des informations, alors que la lecture intensive et longue recourrait au codex conventionnel ». Mais on peut s'interroger, là encore, sur la nouveauté prêtée à ce genre de lecture encouragé par la « révolution numérique ». Les trois niveaux de lecture distingués par Darnton recouvrent en fait trois pratiques usuelles : l'une privilégie la lecture du texte, l'autre celle des notes et des annexes, la troisième celle de la bibliographie... En ce qui concerne enfin la recherche d'une ligne de conduite (qu'il s'agisse de recettes de cuisine, de conseils de bricolage ou d'éducation des enfants), elle va souvent de pair, aujourd'hui comme hier, avec le zapping et le recueil de citations ou de morceaux choisis : le recueil de citations dans l'Angleterre de la Renaissance, ne visait ni " le divertissement » (usage « d'évasion "), ni même l'érudition (usage " didactique ») : il s'agissait de trouver des repères en ces temps tumultueux, de «lire pour agir » (usage « éthique ») (Darnton

$2011: 41)$

\subsection{Une lecture désorientée?}

La prolifération textuelle préexistait à la « révolution numérique ", mais elle s'en trouve démultipliée : « Notre bibliothèque est plus large que notre mémoire. C'était déjà le cas pour les livres que
Likewise, concerning the exclusively educational use of scientific texts, it seems that the digital form encourages, rather than invents, reading on many levels that Darnton (2011: 175) associates with "hypertexts." He writes that it "incites us towards a new type of reading, some readers are content with quickly browsing the story, others wish to read vertically and follow through certain themes in depth with further literature and essays. A third group of readers browse in unexpected directions, looking for connections that respond to their own interests or reshape the material to organize it in their own way. [...] Computer screens are thus used to select and search for information, while intensive and long reading resorts to the conventional codex." However, we can once again question whether this kind of reading that is encouraged by the digital revolution is really that new. The three reading levels distinguished by Darnton in fact cover three common practices: the first is used for reading a text, the second for reading notes and annexes, and the third for bibliographies... As for searching for guidelines (whether this be recipes, DIY tips, or child education), in the past as well as nowadays, it often goes hand in hand with "zapping" and collecting quotations from chosen texts. Quotation collections in the Renaissance were neither made for "entertainment" (escapism) nor "educational" purposes; they were about finding landmarks in tumultuous times, about "reading to act" ("ethical" use) (Darnton 2011: 41).

\subsection{Disoriented Reading?}

Textual proliferation existed before the digital revolution, but it is now reinforced: "Our library is larger than our memory. That was already the case for the books that we physically own, and it's 
nous possédons matériellement, cela devient un labyrinthe pour nos livres immatériels » (Bon $2011: 51$ ). Cette prolifération peut alors devenir un obstacle à la connaissance : pour la maîtriser il

faut des instruments capables de trier, classer, hiérarchiser ${ }^{26} \ldots$

Le foisonnement des sollicitations propres à l'univers numérique et les interruptions qu'elles provoquent conduisent les usager-ère's intensif.ve.s à s'interroger sur différentes formes d'« addiction paresseuse » et sur le caractère chronophage d'internet :

« C'est épouvantable. Moi, je perds un temps avec ça incroyable [...]. Ça amplifie des travers déjà bien installés-là, je ne sais pas, des fois, il faudrait que je ferme l'ordinateur carrément ! D’ailleurs, si je veux vraiment travailler, il ne faut pas que je le laisse devant moi parce que sinon, pof !, je veux regarder, je jette un œil sur les dernières nouvelles du Figaro à 16h15, à 16h20... c'est ridicule quoi ! » (Michèle Q., chercheuse en sciences sociales retraitée, 65 ans, équipée d'une tablette.)

«Ce qui me fait peur, c'est qu'on a beaucoup plus de moyens de perdre son temps. Par rapport à la lecture, c'est là où c'est terrible. J'observe pour moi qu'il y a très peu de choses que je lis qui font partie d'une espèce de plan de lecture où je m'étais dit: "Tiens, je vais lire ces cinq livres parce que je vais apprendre des trucs, etc." " (Damien H., développeur de logiciel, 35 ans, équipé en tablette, technophile.)

«Ça me prenait du temps de lecture parce qu'il faut lire ce qu'écrivent les autres, c'est une des raisons pour lesquelles

26. «Alors que la crainte de l'effacement a obsédé les sociétés européennes de la première modernité », note Chartier (2005:7), la « révolution numérique » amplifie le danger d'une prolifération textuelle incontrôlable : « un discours sans ordre ni limites », « un excès d'écrits qui multiplie les textes inutiles et étouffe la pensée sous les discours accumulés ». become a maze for our electronic books" (Bon 2011: 51). This proliferation can thus become an obstacle to knowledge: to master it we need methods for sorting, classifying, and ranking ${ }^{26}$.

The abundance of temptations characteristic of the digital world and the disruption that they provoke lead intensive users to reflect on various forms of "lazy addiction" and the time-consuming nature of the internet.

"It's awful. I waste an incredible amount of time over it ... it accentuates inherent weaknesses; I don't know, sometimes I want to just shut down my computer! What's more, if I really want to work, I can't leave it in front of me because otherwise, pouf! I want to have a look, check the latest news on Le Figaro at 4:15 pm, then at 4:20 pm ... It's ridiculous!" (Michèle Q., 65 years old, retired social science researcher, owns a tablet.)

"What scares me is that there are many more ways of wasting our time, compared with reading, that's what's terrible. For me, I can tell that very few things that I read are part of a kind of reading plan, where I would have said to myself: 'So, I'm going to read these five books because I will learn something."' (Damien H., software developer, 35 years old, owns a tablet, technophile.)

"One of the reasons I stopped using Facebook was that it took up my reading time because I had to read what

26. Chartier (2007: 7) notes that: "Just as the fear of eradication obsessed early modern European societies," the "digital revolution" amplifies the danger of an uncontrollable textual proliferation: "A discourse without order or limits," "an excess of writings that multiplies useless texts and smothers thought under accumulated discourse." 
j'ai arrêté Facebook, c'est que ça me faisait lire trop de merdes. Je lisais des choses intéressantes, mais le taux de conneries... normal sur ce genre de choses où il n'y a aucun filtrage, voilà ce n'était plus possible. » (Laurence C., chercheuse en Lettres, 38 ans, équipée d'une liseuse.)

« Je pense qu'on a à faire avec l'infobésité. L'infobésité, c'est quand t'as plus de réponses que de questions. Du coup, avant de lire un truc sur le Web, je me suis entraîné à écrire la question que je me pose. Et je me dis: "Je ne vais pas le lire si je me pose pas la question." Parce qu'il y a curiosité et curiosité. $90 \%$ de la curiosité sur internet sert à rien. II faut se dire : "Pourquoi j'irais voir cette page ?", j'essaie de plus en plus de me dire : "Tiens, qu'est ce que je m'attends à apprendre sur cette page ?" » (Damien $\mathrm{H}$., développeur de logiciels, 35 ans, équipé en tablette, technophile.)

Certain·e.s enquêté.e.s mentionnent ainsi le risque de « digressions » incontrôlées dans leur recherche d'informations :

«Au lieu d'allumer la télé, je peux allumer l'ordinateur et me laisser entraîner à n'importe quoi, c'est ce qu'on appelle surfer. » (Guy W., chercheur en linguistique retraité, 65 ans, équipé d'une tablette.)

«Quand tu surfes sur Internet, tu n'es pas forcément super réactif, en tout cas t'as tendance à beaucoup divaguer. Moi, je fonctionne comme ça, je lis un article et souvent tu vas voir un renvoi, etc. Tu rebondis sur d'autres choses assez facilement, c'est l'empire de la digression. Tu voulais lire un truc et tu te retrouves à en avoir lu cinquante autres. ” (Jérôme G., chargé de projet TIC, 32 ans, équipé d'une tablette.)

Si l'on admet enfin que « la continuité de la textualité numérique sur la surface de l'écran [rend] moins immédiatement perceptible que l'ordre hiérarchisé du monde des imprimés, l'inégale crédibilité everyone else was writing, it made me read too much crap. I read interesting things, but also so much bullshit... It's normal for this kind of unfiltered medium, but it wasn't possible anymore." (Laurence C., 38 years old, literature researcher, owns an e-reader.)

"I think we're dealing with infobesity here. Infobesity is when you have more answers than questions. So before reading something online, I have trained myself to write down the question I was asking, and to think to myself: 'I won't read it if it doesn't answer my question.' There are different kinds of curiosity. Ninety per cent of online curiosity is useless. You have to ask yourself: 'Why should I check out this page?'. I'm always trying to tell myself: 'What do I expect to learn on this page?"' (Damien H., 35 years old, software developer, owns a tablet, technophile.)

Some participants also mention the risk of uncontrolled "digressions" in the search for information:

"Instead of switching on the television, I can switch on my computer and get carried away by anything, that's what they call surfing." (Guy W., 65 years old, retired linguistics researcher, owns a tablet.)

"When you surf the internet, you're not always very reactive, you tend to drift a lot. That's how I work, I read an article and then often get referred to something else, and so on. You bounce off other things quite easily, it's the empire of digressions. You wanted to read one thing and you end up reading fifty others." (Jerome G., 32 years old, ICT project manager, owns a tablet.)

If we admit that "the continuity of digital textuality on the screen's surface [is] less immediately perceptible than the hierarchical world of prints, the unequal credibility of discourse" (Chartier 2008: 60), 
des discours " (Chartier $2008: 60$ ), on peut se demander comment préserver de la désinformation et/ou de l'allodoxia les lecteur.rice.s les moins averti·e·s. En fait, il semble que les livres « imprimés sur le papier ou conservés dans des serveurs [...] incarnent le savoir et [que] leur autorité découle de bien autre chose que de la technologie qui entre dans leur fabrication » (Darnton 2011:18), à commencer par celle de leur auteur-rice ou de leur éditeur-rice, à qui les lecteur.rice.s confronté.e.s à la pléthore semblent devoir se fier plus que jamais. La numérisation des textes n'exclut ni les éditeur.rice.s, ni les auteur.rice.s, ni les titres de presse (les journaux en ligne ont été créés par des journalistes consacré·e·s), de sorte que la crainte d'un nivellement éditorial et auctorial semble vaine. En ce qui concerne, plus spécifiquement, l'information, « libérée de ses ancrages conventionnels » et ouvrant ainsi des possibilités de désinformation à l'échelle mondiale, "faut-il penser que notre époque donne un accès sans précédent à l'information, mais que celle-ci est de moins en moins fiable ? » (Darnton 2011 : 74). Sans doute faut-il considérer qu'aujourd'hui comme hier, «la nouvelle n'est pas ce qui s'est passé mais un récit de ce qui s'est passé " (Darnton 2011 : 75), que la presse « en ligne » n'est pas plus que la presse « papier » « une fenêtre transparente » ouverte sur le monde, mais un recueil de " récits écrits par des professionnels selon les conventions propres à leur métier ". S'il est vrai que, indépendamment du support, la presse informe plus "sur la façon dont des contemporains ont interprété les événements " qu'elles ne sont " une connaissance fiable de ces mêmes événements » (Darnton 2011 : 77), la presse en ligne n'est ni plus ni moins crédible que la presse « papier » : la croyance qui lui est accordée vaut ce que vaut le capital symbolique accumulé par le titre et/ou l'auteur-rice. De ce point de vue, l'enquête invite à supposer que la banalisation de la pratique plus ou moins systématique de la revue we can reflect upon how to protect ourselves from misinformation and/or the allodoxia typical of ill-advised readers. In fact, it seems that books "printed on paper or kept on servers [...] incarnate knowledge, and [that] their authority flows from something else than the technology that goes into their making" (Darnton 2011: 18 ), starting with that of the author or editor, who need to be trusted more than ever by overwhelmed readers confronted with a plethora of choices. The digitization of texts excludes neither editors nor authors, nor press publications (online newspapers were created by dedicated journalists), so the fear of editorial and authorial levelling seems unfounded. News items more specifically are "freed from their conventional anchoring," which thus opens up world-scale misinformation possibilities: "Must we believe that our era gives us unprecedented access to information, but that it is less and less reliable?" (Darnton 2011: 74). We must without doubt consider that today, just like yesterday, "news isn't what happened it's a story about what happened" (Darnton 2011: 75); "online" media is no more a simple "transparent window" open onto the world than the print press, but rather a "collection of stories written by professionals according to the conventions of their trade." If one can say that the press, independently of its medium, informs us about "the way that events were interpreted at the time" and that it is merely "reliable knowledge of those same events" (Darnton 2011: 77), then online press is neither more nor less credible than the print press. The belief that is bestowed upon both is worth the same as the author's or newspaper's accumulated symbolic capital. From this point of view, the survey leads us to suppose that the trivialization of the more or less systematic practice of press reviews, which is authorized by the online press, consolidates the "field effect" and leads to a kind of mutual control ${ }^{27}$.

27. On the contrary, Raffaele Simone (2012: 234) notes that "if the information age had replaced experience with news and narrative temporality with the 
de presse, permise par la presse en ligne, consolide « l'effet de champ » et induit une sorte de contrôle mutuel ${ }^{27}$.

\subsection{Le déclin de la culture écrite au profit de l'audiovisuel ?}

En définitive, l'enquête montre que les effets «observables » de la « révolution numérique » sur les pratiques de lecture restent très limités : la continuité prévaut en matière de lecture littéraire et les changements en matière de lecture d'information accentuent les modalités antérieures. La "révolution » partout annoncée des pratiques de lecture ne semble pas vraiment à l'ordre du jour. Pour conclure, on s'interrogera, dans la perspective de longue durée qu'adopte Pierre Bergounioux (2019), sur les effets liés à la présence accrue de l'audiovisuel sur internet. La " théorie de la convergence des médias " (Nora \& Minc 1978), liée au développement des technologies informatiques, n'est pas récente : elle est favorisée par la diffusion des supports numériques connectés qui permettent d'avoir accès sur un seul support, aux images, textes, sons, etc. "À la différence du passé, la lecture n'est plus aujourd'hui le principal instrument d'acculturation à la disposition de l'homme contemporain ; son rôle dans la culture de masse a été sapé par la télévision, dont la diffusion s'est très rapidement généralisée dans les trente dernières années. [...] Globalement, on peut affirmer que, de nos jours, dans le monde entier, la formation et l'information des masses, dévolues pendant des siècles à l'imprimé, donc à l'acte de lire, sont passées aux moyens audiovisuels, à l'écoute et à la vision, comme le nom l'indique », constate Armando Petrucci (1997 : 418-419).

27. À l'inverse, Raffaele Simone (2012 : 234) remarque que « si l'ère de l'information avait substitué l'actualité à l'expérience et l'éternel présent à la temporalité narrative », le « temps réel » de la presse numérique (l'information en continu) « a tué l'explication ».

\subsection{The Decline of Written Culture in Favour of Audiovisual Media?}

Ultimately, the survey shows that the "visible" effects of the digital revolution on reading habits are very limited: when it comes to the reading of literature, continuity prevails, and the changes in reading for information accentuates pre-existing methods. The revolution in reading habits that was announced everywhere does not seem to be happening.

We can conclude by taking Bergounioux's (2019) long-term perspective and questioning the effects linked to the increasing presence of audiovisual media on the internet. The "theory of media convergence" (Nora \& Minc 1978), linked to the development of information technology, is not recent. It is supported by the spread of connected digital mediums which allow access to images, text, sound etc. on one single medium. Armando Petrucci (1997: 418419) writes: "Nowadays, reading isn't the main acculturation device available to modern man anymore; its role in mass culture has been undermined by television, whose use has quickly spread over the last thirty years. [...] We can assert that, nowadays, throughout the world, the formation and information on a mass scale-vested in print for years, and thus to the act of reading-has mutated to audiovisual means, to hearing and sight, as its name indicates."

By including sound and images in the text, the digital revolution can now associate "listening" and "seeing" with reading. Pierre Bergounioux (2019) remarks with wonder: "I see children in front of a screen, where explanatory texts and predicted thumbnails appear instantly. Everything is literal, coloured, perfect. It is not

eternal present," the "real time" of digital press (continuous news) "has killed explanation." 
En incluant le son et l'image dans le texte, la « révolution numérique " peut désormais associer « écoute » et « vision » à la lecture : « je vois les enfants devant l'écran où surgit, instantanément, le texte explicatif et la vignette escomptée, littérale, colorée, parfaite. II n'y manque même pas la vie puisqu'on trouve aussi des images en mouvement, des films ", s'émerveille Bergounioux (2019). Cette offre numérique rencontre un public d'autant plus disposé à s'y prêter qu'il y est prédisposé par la « révolution audiovisuelle »: " pour la première fois, le livre et les autres produits imprimés se trouvent confrontés à un public, réel et potentiel, qui se nourrit d'autres techniques d'information et qui a acquis d'autres méthodes d'acculturation, celle des médias audiovisuels, qui a pris l'habitude de lire des messages produits par des moyens électroniques " (Petrucci $1997: 419)^{28}$. L'écran de l'ordinateur, à la différence de ceux du cinéma ou de la télévision, porte aussi des textes : "à l'ancienne opposition entre, d'un côté, le livre, l'écrit, la lecture et, de l'autre, l'écran et l'image, est substituée une situation nouvelle qui propose à la culture écrite ${ }^{29}$ un nouveau support » (Chartier 2007 : 249). II n'y a pas, là non plus, solution de continuité : le livre «papier » pouvait inclure, depuis longtemps, des illustrations ${ }^{30}$. On

28. De même, selon Olivier Donnat (2012: 47), « la diffusion d'internet a été d'autant plus rapide et ses effets d'autant plus massifs que le terrain avait été largement préparé par la montée en puissance régulière des consommations audiovisuelles depuis 1960. Les jeunes générations ayant grandi avec la télévision ont un imaginaire fortement structuré par l'image et par le son, ce qui les rend peut-être moins sensibles aux formes d'expression comme la littérature qui suppose de faire fonctionner son propre imaginaire à partir des mots et des mots seuls ".

29. Mais également à la culture audiovisuelle...

30. Michel Melot (2007: 88-89) rappelle que « la presse tarda à intégrer l'image longue et coûteuse à reproduire. Ce ne fut qu'en 1789 qu'on vit un périodique illustré, Le Cabinet des modes, publié à Amsterdam, insérant dans ses petits cahiers, tous les quinze jours, deux eaux-fortes coloriées à la main. Mais $n$ les bois gravés, ni les tailles-douces ne permettaient une production rapide. even lacklustre, since you also find moving images and films." This digital offer is met by an audience that is ready to play along, predisposed by the "audiovisual revolution." "For the first time ever, books and other printed products are confronted with a real and potential audience that is being fed with other information techniques and has acquired other acculturation methods, from audiovisual media, and gotten used to reading messages produced by electronic means" (Petrucci 1997: 419) ${ }^{28}$. Computer screens differ from cinema or television screens in that they also display text. "We used to contrast books, writing, and reading with screens and images, but now a new situation has arisen which offers a new medium for written culture ${ }^{29 "}$ (Chartier 2007b: 249). There is no rupture here either, since the "paper" book had long been able to include illustrations ${ }^{30}$. We can thus suppose that, if there has been such a "cultural revolution," it happened before the digital revolution, and that we are attributing the digital revolution and the opposition it may have engendered between "screen" reading and

"paper" reading with the effects of the "audiovisual revolution ${ }^{31}$."

28. Similarly, according to Olivier Donnat (2012: 47), "internet distribution happened all the faster and its effects were all the greater because the ground had been prepared by the regular increasing power of audiovisual use since the 1960s. Younger generations that grew up with television have an imagination that is necessarily structured by images and sounds, which may make them less sensitive to forms of expression such as literature, which calls upon one's own imagination through written words."

29. But also, to audiovisual culture.

30. Michel Melot (2007: 88-89) reminds us that "the press was late in integrating images, which were lengthy and expensive to reproduce. It was only in 1789 that an illustrated journal, Le Cabinet des modes, was published in Amsterdam. It included hand-coloured etchings in its little booklets every two weeks. It was only with the invention of lithography in 1796 that illustrated newspapers were born."

31. On this topic, Bernard Lahire (2012: 63) notes that "cinema contributed to [the] marginalization [of literary culture] because it proposes an experience in a limited time frame, that a novel could offer over a few days or a few 
peut alors supposer que, si " révolution culturelle » il y a eu, elle est antérieure à la "révolution numérique » et qu'on impute à la « révolution numérique » et à l'opposition qu'elle aurait engendrée entre lecture " écran » et lecture " papier », les effets de la « révolution audiovisuelle ${ }^{31}$.

Mais, dans la mesure où la « révolution numérique » relaie la “ révolution audiovisuelle ${ }^{32}$, on peut supposer qu'elle contribue à décourager la lecture et favorise ainsi une sorte de retour à la " culture orale » du plus grand nombre ${ }^{33}$. De ce point de vue, on peut se demander si la "révolution numérique » constitue toujours " un progrès » et s'interroger, comme invite à le faire Jacques Bouveresse sur « les effets négatifs du progrès ". " II est extrêmement rare, note-t-il, que ce qui a l'air de représenter une avancée n'implique pas simultanément un recul ». De ce point de

Seule la lithographie, inventée en 1796, put donner naissance à une presse d'actualité illustrée ».

31. À cet égard, Bernard Lahire $(2012: 63)$ note que « le cinéma a contribué à [la] marginalisation [de la culture littéraire] parce qu'il propose en un temps limité une expérience qu'un roman propose sur plusieurs jours, et parfois plusieurs semaines. Celui qui a besoin de s'évader ou de rentrer dans des mondes de fiction et d'aventure choisit aujourd'hui plus volontiers le cinéma qui a tout bouleversé ».

32. Selon Emmanuel Durand (2004 : 23-24), « les contenus vidéo deviennent amplement majoritaires dans le trafic Internet global : aux États-Unis, à la mi-2014, les deux seules plateformes Netflix et Youtube représentaient plus de la moitié du trafic Internet » et « la part de la consommation de Youtube sur mobile est passée de $6 \%$ en 2011 à $40 \%$ dans le monde à peine deux ans plus tard ». Parallèlement, "le téléviseur demeure le cœur de la consommation des contenus audiovisuels. Le début de l'année 2014 a vu la consommation moyenne des Français de plus de quinze ans atteindre une durée quotidienne de trois heures cinquante-deux minutes (en diminution toutefois de huit minutes à la même période en 2013) ».

33. Raffaele Simone $(2012: 34-35,36)$ rappelle que « nous devons ce que nous savons au fait de l'avoir lu, vu ou entendu ». De ce point de vue, nous serions passés « de l'oralité à l'écriture, puis de la lecture à la vision et à l'écoute ».
But as far as the digital revolution relays the "audiovisual revolution, ${ }^{32}$ we can suppose that it contributes towards discouraging reading, and thus favours a kind of return to "oral culture" on a mass scale ${ }^{33}$. Here, we can question whether the digital revolution necessarily constitutes "progress," and reflect upon the "negative effects of progress," as Jacques Bouveresse urges us to do. He notes that often, a step forward simultaneously represents a step back. In this vein, it seems to me that few technologies compare with the digital in their ability to create "a euphoric vision of progress without really knowing what it is, or why we should rejoice about it" (Bouveresse 2017: 19). Thus we can reflect on what the possible effects of an ebb in "written culture" would be, along with the loss of what marks it apart from "oral culture": the objectification of discourse, a more acute consciousness of syntactic and semantic language structures, and a sharper perception of internal inconsistencies

weeks. Nowadays, someone looking to escape or enter worlds of fiction and adventure tends to go to the cinema, which has changed everything."

32. According to Emmanuel Durand (2004: 23-24), "video content has become abundantly predominant in global internet traffic: in the United States, in mid-2014, Netflix and YouTube alone represented more than half of internet traffic" and "the percentage of YouTube mobile consumption went from $6 \%$ in 2011 to $40 \%$ in the world, a mere two years later." In parallel, "television stil makes up the core of audiovisual content use. Early 2014 saw consumption amongst French people over fifteen reach a daily average of three hours and fifty-two minutes (though eight minutes less than the same period in 2013)."

33. Raffaele Simone $(2012: 34-35,36)$ reminds us that "we owe what we know to the fact of having read, seen or heard it." From this point of view, we would thus have gone "from orality to writing, then from reading to vision and hearing." 
vue, il me semble qu'il y a peu de technologies qui donnent lieu, autant que le numérique, à « une vision euphorique du progrès sans qu'on sache vraiment de quoi il s'agit, ni pourquoi il faut s'en réjouir » (Bouveresse 2017 : 19). Ainsi peut-on s'interroger, par exemple, sur ce que pourraient être les effets d'un reflux de la « culture écrite " et de la perte de ce qui en fait la spécificité par rapport à la " culture orale » : l'objectivation du discours, une conscience plus aiguë des structures du langage tant syntaxiques que sémantiques, la perception facilitée des inconsistances et des contradictions internes, le développement de l'examen réflexif, de l'esprit critique et de l'art du commentaire, les modes de pensée associés au tableau, à la liste, à la formule (i.e. à « la raison graphique $»)^{34}$. Dans cette perspective, le déplacement du plus grand nombre vers la culture orale creuserait l'écart entre codes linguistiques sommaires et codes sophistiqués, entre langue vernaculaire et langue scolaire, c'est-à-dire aussi entre classes sociales et consoliderait le monopole des lettré e.s sur la culture écrite quel qu'en soit le support.

Gérard Mauge

Centre européen de sociologie et de science politique-Centre de sociologie européenne (CESSP-CSE)

\section{Références bibliographiques}

Beliste Claire (2011). Lire dans un monde numérique. Villeurbanne, Presses de l'Enssib.

34. Voir (Goody, 1979). Dans la même perspective, Raffaele Simone (2012: 72 $73,79,97-98-99$ ) oppose le rythme « autoguidé » de la lecture (qui peut ainsi être corrigée) au rythme « hétéroguidé » de la vision ou de l'écoute (par ailleurs, difficiles à « citer »), la « conversion déictique » et la possibilité de se corriger qu'implique le passage de l'oral à l'écrit. and contradictions, the development of reflexive inspection, of the spirit of critique and the art of commentary, of the modes of thinking associated with tables, lists and formula (i.e. to "graphic reasoning") ${ }^{34}$. Moving towards oral culture on a wider scale would expand the gap between basic and sophisticated linguistic codes, between vernacular and scholarly discourse, and thus between social classes, strengthening the control of well-read individuals over written culture, regardless of the medium.

Gérard Mauger Centre européen de sociologie et de science politique-Centre de sociologie européenne (CESSP-CSE)

\section{References}

BELISLE Claire (2011). Lire dans un monde numérique. Villeurbanne, Presses de l'Enssib.

34. See Goody (1979). In the same vein, Raffaele Simone (2012: 72-73, 97-99) contrasts the "self-guided" rhythm of reading (that can thus be corrected) with the "hetero-guided" rhythm of seeing or hearing (which is incidentally difficult to "cite"), "deictic conversion," and the possibility to correct oneself that the passage from orality to writing implies. 
BenHAmOU Françoise (2009). « Le livre numérique. Ni tout à fait le même, ni tout à fait un autre... ». Esprit 2009, 3-4 : 73-85. [Consulté le 17 juillet 2020.].

BenHAmou Françoise (2014). Le Livre à l'heure numérique. Papiers, écrans, vers un nouveau vagabondage. Paris, Seuil.

Bergounioux Pierre \& BarRal Jacquie (2019). Le Corps de la lettre. Paris, Fata Morgana.

Bienvault Hervé (2012). « De la lecture numérique ». In BESSARD-BANQUY Olivier (dir.). Les Mutations de la lecture. Bordeaux, Presses Universitaires de Bordeaux.

Bon François (2011). Après le livre. Paris, Seuil.

BOURDIEU Pierre \& PASSERON Jean-Claude (1963). "Sociologues des mythologies et mythologies des sociologues ». Les Temps Modernes, $211: 998-1021$

BOUVERESSE Jacques (2017). Le Mythe moderne du progrès. Marseille, Agone.

CARR Nicholas (2008). «Is Google Making Us Stupid ? ». The Atlantic, $1(7)$.

Certeau Michel (DE) (1990). L'Invention du quotidien, 1, Arts de faire. Paris, Gallimard, 1990.

ChARTIER Anne-Marie \& HÉBrARD Jean (2000). Discours sur la lecture (1880-2000). Paris, BPI Centre Pompidou/Fayard.

CHARTIER Roger (1997). Le Livre en révolutions (entretiens avec Jean Lebrun). Paris, Textuel.

CHARTIER Roger (2005). Inscrire et effacer. Culture écrite et littérature (XI $X V I I I^{e}$ siècle). Paris, Gallimard/Seuil.

ChARTIER Roger (2007). « La mort du lecteur ? ». In MollieR Jean-Yves (dir.), Où va le livre ?. Paris, La Dispute.

ChARTIER Roger (2008). Écouter les morts avec les yeux. Paris, Collège de France/Fayard.
Benhamou Françoise (2009). "Le livre numérique. Ni tout à fait le même. ni tout à fait un autre...." Esprit, 3-4: 73-85. [Accessed on 17 July 2020.]

Benhamou Françoise (2014). Le Livre à l'heure numérique. Papiers, écrans, vers un nouveau vagabondage. Paris, Seuil.

Bergounioux Pierre \& BarRal Jacquie (2019). Le Corps de la lettre. Paris, Fata Morgana.

Bienvault Hervé (2012). "De la lecture numérique." In Bessard-BanquY Olivier (ed.). Les Mutations de la lecture. Bordeaux, Presses Universitaires de Bordeaux.

Bon François (2011). Après le livre. Paris, Seuil.

Bourdieu Pierre \& PASSERON Jean-Claude (1963). "Sociologues des mythologies et mythologies des sociologues." Les Temps Modernes, 211 : 998-1021.

Bouveresse Jacques (2017). Le Mythe moderne du progrès. Marseille, Agone.

CARR Nicholas (2008). "Is Google Making Us Stupid?." The Atlantic, 1(7).

Certeau Michel (DE) (1984). The Practice of Everyday life. Translated by Steven Rendall. Berkeley, University of California Press, 1984.

Chartier Anne-Marie \& HÉBrARD Jean (2000). Discours sur la lecture (1880-2000). Paris, BPI Centre Pompidou/Fayard.

CHARTIER Roger (1997). Le Livre en révolutions (entretiens avec Jean Lebrun). Paris, Textuel.

CHARTIER Roger (2007). Inscription and Erasure: Literature and Written Culture from the Eleventh to the Eighteenth Century. Translated by Arthur Goldhammer. Philadelphia, University of Pennsylvania Press.

ChARTIER Roger (2007b). "La mort du lecteur?.” In Mollier Jean-Yves (ed.), Où va le livre?. Paris, La Dispute.

Chartier Roger (2008). Écouter les morts avec les yeux. Paris, Collège de France/Fayard 
CHARTIER Roger \& JABLONKA Ivan (2008b). « Le livre : son passé, son avenir », La Vie des idées. [Consulté le 15 juillet 2019.]

DARnTON Robert (2011). Apologie du livre. Demain, aujourd'hui, hier, Paris, Gallimard.

Defrance Jacques (1996). Quand lire, c'est faire... Lectures de conseils pratiques (rapport). Paris, CSU.

DonnAT Olivier (2009). Les Pratiques culturelles des Français à l'heure du numérique. Enquête 2008. Paris, La Découverte.

DONNAT Olivier (2012). «Gardons-nous de trop idéaliser la lecture des temps passés ». In BessaRd-BanquY Olivier (dir.). Les Mutations de la lecture. Bordeaux, Presses Universitaires de Bordeaux : 39-49.

DURAND Emmanuel (2014). La Menace fantôme. Les Industries culturelles face au numérique. Paris, Presses de la Fondation nationale des sciences politiques.

EISEnStein Elizabeth L. (1979). The Printing Press as an Agent of Change. Cambridge, Cambridge University Press.

Gaudric Paul, Mauger Gérard, Zunigo Xavier (2015). Lectures numériques. Une enquête sur les grands lecteurs. Villeurbanne, Presses de l'Enssib.

Goody Jack (1979). La Raison graphique. La domestication de la pensée souvage. Traduction et présentation de BAZIN Jean \& BENSA Alban. Paris, Minuit.

Granjon Fabien \& Le Foulgoc Aurélien (2010). «Les usages sociaux de l'actualité. L'expérience médiatique des publics internautes », Réseaux, 160-161: 225-253.

LAHIRE Bernard (2012). «C'est un nouveau style de vie qui est en voie de s'imposer : le modèle de l'honnête homme cultivé est battu en brèche ». In BessaRd-BANQUy Olivier (dir.). Les Mutations de la lecture. Bordeaux, Presses Universitaires de Bordeaux : 51-67.

LE FLOCH Patrick \& SONNAC Nathalie (2013). Économie de la presse à l'ère numérique. Paris, La Découverte.
Chartier Roger \& Jablonka Ivan (2013). "The Book: Its Past, Its Future. An interview with Roger Chartier", Books and Ideas. [Accessed on 15 July 2019.]

DARnton Robert (2009). The Case for Books. Past, present and future, New York: PublicAffairs.

Defrance Jacques (1996). Quand lire, c'est faire... Lectures de conseils pratiques (rapport). Paris, CSU.

DonNat Olivier (2009). Les Pratiques culturelles des Français à I'heure du numérique. Enquête 2008. Paris, La Découverte.

DONNAT Olivier (2012). "Gardons-nous de trop idéaliser la lecture des temps passés." In BESSARD-BANQuY Olivier (ed.). Les Mutations de la lecture. Bordeaux, Presses Universitaires de Bordeaux: 39-49.

DURAND Emmanuel (2014). La Menace fantôme. Les Industries culturelles face au numérique. Paris, Presses de la Fondation nationale des sciences politiques.

EISEnstein Elizabeth L. (1979). The Printing Press as an Agent of Change. Cambridge, Cambridge University Press.

Gaudric Paul, Mauger Gérard, Zunigo Xavier (2015). Lectures numériques. Une enquête sur les grands lecteurs. Villeurbanne, Presses de l'Enssib.

Goody Jack (1977). The Domestication of the Savage Mind. Cambridge/ London/New York, Cambridge University Press.

Granjon Fabien \& Le Foulgoc Aurélien (2010). "Les usages sociaux de l'actualité. L'expérience médiatique des publics internautes." Réseaux, 160-161: 225-253.

LAHIRE Bernard (2012). "C'est un nouveau style de vie qui est en voie de s'imposer: le modèle de l'honnête homme cultivé est battu en brèche." In Bessard-Banquy Olivier (ed.). Les Mutations de la lecture. Bordeaux, Presses Universitaires de Bordeaux: 51-67.

LE FLOCH Patrick \& SONNAC Nathalie (2013). Économie de la presse à l'ère numérique. Paris, La Découverte. 
Le Hay Viviane, Vedel Thierry, ChanvRIL Flora (2011). « Usages des médias et politique : une écologie des pratiques informationnelles ». Réseaux, $170: 45-73$

Mc KenZIE Donald F. (1991) [1986]. La Bibliographie et la sociologie des textes. Traduit de l'anglais par Marc Amfreville. Préface de Roger Chartier. Paris, Cercle de la Librairie.

MAUGER Gérard (1992). «La lecture en baisse. Quatre hypothèses ». Sociétés contemporaines, 11-12:221-226.

MAuger Gérard \& Poliak Claude (1998). « Les usages sociaux de la lecture ». Actes de la recherche en sciences sociales, 123 : 3-24.

Mauger Gérard, Poliak Claude, Pudal Bernard (2010) [1999]. Histoires de lecteurs. Bellecombe-en-Bauges, Le Croquant.

Melot Michel (2007). Une brève histoire de l'image. Paris, J.-C. Béhar.

MolLIER Jean-Yves (2014). « La troisième révolution des manières de lire ». L'Humanité, 28 février.

NoRA Simon \& Minc Alain (1978). L'Informatisation de la société. Rapport à M. le Président de la République. Paris, Seuil.

Octobre Sylvie (2014). Deux pouces et des neurones. Les cultures juvéniles de l'ère médiatique à l'ère numérique. Paris, Ministère de la Culture et de la Communication.

PetRuccl Armando (1997). « Lire pour lire. Un avenir pour la lecture ». In CAVAllo Guglielmo \& Chartier Roger (dir.). Histoire de la lecture dans le monde occidental. Paris, Seuil : 401-425.

RICROCH Layla \& Roumier Benoît (2011). « Depuis 11 ans, moins de tâches ménagères, plus d'Internet ». INSEE Première, 1377.

SIMONE Raffaele (2012). Pris dans la toile. L'esprit aux temps du web. Paris, Gallimard.

Vincent GÉRARD Armelle \& PONCET Julie, 2019, Les Français et la lecture-2019, IPSOS-CNL. [Consulté le 15 juillet 2019.]

Wolf Maryanne (2008). Proust and the Squid. The Story and Science of the Reading Brain. New York, Harper Perennial.
Le Hay Viviane, Vedel Thierry, ChanvrIL Flora (2011). "Usages des médias et politique: une écologie des pratiques informationnelles." Réseaux, 170: 45-73.

Mc KenZIE Donald F. (1986). Bibliography and the Sociology of Texts. London, The British Library.

MAUGER Gérard (1992). "La lecture en baisse. Quatre hypothèses." Sociétés contemporaines, 11-12: 221-226.

MAuger Gérard \& Poliak Claude (1998). "Les usages sociaux de la lecture." Actes de la recherche en sciences sociales, 123: 3-24.

Mauger Gérard, Poliak Claude, Pudal Bernard (2010) [1999]. Histoires de lecteurs. Bellecombe-en-Bauges, Le Croquant.

Melot Michel (2007). Une brève histoire de l'image. Paris, J.-C. Béhar. MolLIER Jean-Yves (2014). "La troisième révolution des manières de lire." L'Humanité, 28 février.

NoRA Simon \& Minc Alain (1980). The Computerization of Society: A Report to the President of France. Cambridge, MIT Press.

ОстовRE Sylvie (2014). Deux pouces et des neurones. Les cultures juvéniles de l'ère médiatique à l'ère numérique. Paris, Ministère de la Culture et de la Communication.

Petrucci Armando (1999). "Reading to Read: A Future for Reading". In Cavallo Guglielmo \& ChaRTIER Roger (eds.). A History of Reading in the West. Translated by Lydia G. Cochrane. Amherst, University of Massachusetts Press.

Rıcroch Layla \& Roumier Benoît (2011). "Depuis 11 ans, moins de tâches ménagères, plus d'Internet." INSEE Première, 1377.

Simone Raffaele (2012). Pris dans la toile. L'esprit aux temps du web. Paris, Gallimard.

Vincent Gérard Armelle \& Poncet Julie (2019). Les Français et la lecture-2019, IPSOS-CNL. [Accessed on 15 July 2019.]

Wolf Maryanne (2008). Proust and the Squid. The Story and Science of the Reading Brain. New York, Harper Perennial. 